\title{
Akhisar (Manisa), Karahöyük Dağı Çevresinde Yeni Bir Erken Yerleșim: Kocanadas
}

\section{A New Early Settlement Around Akhisar (Manisa), Karahöyük Mount: Kocanadas}

\author{
Aydın Erön ${ }^{1}$ (1)
}

1Sorumlu yazar/Corresponding author: Aydın Erön (Dr. Öğr. Üyesi),

Adnan Menderes Üniversitesi, Fen-Edebiyat Fakültesi, Klasik Arkeoloji Anabilim Dalı,

Aydın, Türkiye

E-mail: aeron@adu.edu.tr

Orcid ID: 0000-0003-1611-2296

Başvuru/Submitted: 01.11.2019 Kabul/Accepted: 02.12.2019

Atıf/Citation: Eron, A. (2019). Akhisar (Manisa), Karahöyük dağı çevresinde

yeni bir erken yerleșim: Kocanadas. Anadolu Araştırmaları-Anatolian Research, 22, 25-54. https://doi.org/10.26650/anar.2019.22.641653

\section{öz}

Karahöyük Dağı Manisa ili, Akhisar ilçe sınırları içerisinde yer almaktadır. Söz konusu alanda 2016-2018 yılları arasında gerçekleştirilen yüzey araştırması çalışmaları sırasında bölgenin erken dönem iskanı konusunda önemli buluntulara ulaşılmıştır. Kocanadas Mevkii'nde yer alan höyük bu açıdan oldukça önemlidir. Yapılan incelemeler sonucunda höyüğün Geç Neolitik Çağ'dan Osmanlı Dönemi'ne kadar iskan gördüğü buluntular ışığında anlaşılmaktadır. Geçmiş yıllarda yapılan araştırmalar sonucunda Manisa il sınırları içerisinde 11 merkezde Geç Neolitik Çağ buluntusu tespit edilmiştir. Kocanadas Mevkii'nde tespit edilen seramik buluntularıyla birlikte bu sayı 12'ye çıkmıştır. Seramik buluntuları ışı̆̆ında Kocanadas Mevkii'nde yer alan höyükte Geç Neolitik-Erken Kalkolitik Çağ iskanının çok yoğun olmadığı anlaşılmaktadır. İlk Tunç Çağı́nda seramik ve küçük buluntu sayısında bir artış yaşandığı tespit edilmiştir. Orta Tunç ve Son Tunç çağı ile birlikte ise buluntu sayısı bir hayli artmıştır. Demir Çağı içerisinde ise yerleşimin önemini koruduğu anlaşılmaktadır. Kocanadas Mevkii'nde bulunan ve Demir Çağı́na tarihlendirilen Lydia seramik örnekleri oldukça önemlidir. MÖ 6. yüzyıldan sonra höyükte iskanının devam ettiği tespit edilmiş, fakat buluntu sayısı bir hayli azalmıştır.

Anahtar Kelimeler: Akhisar, Karahöyük Dağı, Neolitik, Höyük, Lydia

\section{ABSTRACT}

Karahöyük Mount is located in Akhisar, country of Manisa province. During the survey conducted between the years of 2016-2018, significant findings concerning to earliest settling in the region have been attained. In this respect, the mound located in Kocanadas site is immensely important. According to conducted inquires it has been understood that the mound was settled since the Late Neolithic Age until the Ottoman Period. Previous researches, fixed Late Neolithic Age findings in 11 centers in Manisa. With pottery findings in Kocanadas, this is raised to 12 . In the light of the pottery findings it can be understood that settling in Kocanadas during the Late Neolithic and Early Chalcolithic ages was not intense at all. It can be observed that an increase took place in the number of pottery and little findings during the Early Bronze Age. Number of finding belonging to Middle and Late Bronze ages, increased considerably. The settlement maintained its importance during the Iron Age. Lydian pottery 
samples found in Kocanadas belonging to the Iron Age of great importance. It is understood that settlement in the mound continued after $6^{\text {th }}$ century BC, while the number of findings decreased considerably.

Keywords: Akhisar, Karahöyük Mount, Neolithic, Mound, Lydia

\section{EXTENDED ABSTRACT}

In every period of history, people have chosen the place where they will live in line with their instincts, tastes and needs. For this reason, it is not surprising that human beings have lived on the same geography from the first periods of the settlement to the present days. This also applies to Akhisar and its surrounding area.

Karahöyük Mount is located within the boundaries of the Akhisar country of the Manisa province. Karahöyük Mount, which is located in the middle of the fertile Akhisar plain, attracts attention with its location. Approximately $525 \mathrm{~m}$. height of the mountain, north of İstanbul-İzmir highway, and east of the Akhisar-Salihli highway passes, the Akhisar district and naturally Karahöyük Mount are located at a very strategic point.

During the surface survey studies conducted in the mentioned area between the years of 2016-2018, important findings concerning to the earliest settling in the region have been attained. In this respect, the mound located in the Kocanadas site is immensely important. The Kocanadas site is located southwest of Karahöyük Mount. It is $5.3 \mathrm{~km}$ south of the Kayalığlu district and $2 \mathrm{~km}$ west of the Rahmiye district. It is understood that the location of Karahöyük Mount was used in choosing the location of the mound. Strong northern winds are very important in the Akhisar plain. The purpose of protection from these winds should have been decisive in the selection of the settlements located to the south of Karahöyük Mount. The mound was first discovered during the 2017 surveys at the Kocanadas site. Taking into consideration that this land would be cultivated due to agricultural activities, this land was re-examined during 2018 studies.

The mound, which looks like a flat hill, attracts attention with its area. The mound covers an area of $196 \mathrm{~m}$ in a north-south direction, and $172 \mathrm{~m}$ in an east-west direction. Due to agricultural activities, it is very difficult to determine the actual spreading area of the mound. During the surveys conducted in 2017 and 2018, many pottery fragments were found. While the pottery findings increase in the area that we can define as the centre of the mound, and the decrease in the pottery findings towards the skirts of the mound is remarkable.

According to conducted inquires, it has been understood in light of the findings, that the mound was settled since the Late Neolithic Age until the Ottoman Period. Previously conducted researches, fixed Late Neolithic Age findings in 11 centers within the boundaries of the Manisa province. With the pottery findings found in Kocanadas site, this figure was 
raised to 12. The occurrence of the centers that yield Late Neolithic Age findings in city center and south of the city center of Akhisar is not an accident. These early period settlements were encountered in the east and south of the Karahöyük Mount.

It is quite logical that the southern slopes of Karahöyük Mount should be preferred as a settlement. Nowadays, especially in winter, Akhisar and its surroundings are highly affected by the harsh northern winds. This was probably more important during the Late Neolithic Age. The southern skirts of the Karahöyük Mount have been suitable for protection from the harsh northern winds. In addition, the importance of water in the selection of settlements in the Neolithic Age is known. The presence of Lake Yemişli, which is known to be located to the south of Karahöyük Mount, but has been dried recently, is very important in terms of water supply. It can be thought that the lake, which appears to have been found between the Moralı mound and the mound at Kocanadas, gave life to these two settlements starting from the Late Neolithic Age.

In light of the pottery findings, it can be understood that settling in the mound located in the Kocanadas site during the Late Neolithic and Early Chalcolithic Ages was not intense at all. It can be observed that an increase took place in the number of pottery and little findings during the Early Bronze Age. Idols dated to this period are very important. With the Middle Bronze and Late Bronze ages, the number of findings increased considerably. As it is understood, the settlement maintained its importance during the Iron Age. Lydian pottery samples found in the Kocanadas site and dated to the Iron Age are immensely important. It is understood that settlement in the mound continued after the 6th century $\mathrm{BC}$, while the number of findings decreased considerably. 


\section{Giriş}

Karahöyük Dağı Manisa ili, Akhisar ilçe sınırları içerisinde yer almaktadır (Resim. 1-3). Akhisar, 1707 km2'lik yüzölçümü ile Manisa ilinin en büyük ilçesi konumundadır (Koday, Akbaş ve Kaya 2017, s. 445). Günümüzde İstanbul-İzmir yolu üzerinde yer alan ilçenin tarihin her döneminde önemini koruduğu anlaşılmaktadır. Bereketli Akhisar ovasının ortasında yer alan 525 m yüksekliğindeki Karahöyük Dağı ise konumuyla dikkati çeker. Akhisar ilçe merkezinim $4 \mathrm{~km}$ güneybatısında yer alan dağın yerleşim ve tarım açısından daha çok güney eteklerinin tercih edildiği anlaşılmaktadır. Oldukça stratejik bir noktada yer alan yükseltinin kuzeyinden İstanbul-İzmir yolu, doğusundan ise Akhisar-Salihli yolu geçmektedir.

İnsanoğlu tarihin her döneminde yer seçimini içgüdüleri, beğenileri ve ihtiyaçlarını dikkate alarak yapmıştır. Söz konusu nedenle insanoğlunun yerleşik düzene geçtiği ilk dönemlerden başlayarak günümüze kadar aynı coğrafyalar üzerinde yer alması şaşırtıcı değildir. Bu durum Akhisar ilçesi ve çevresi içinde geçerlidir.

Oldukça bereketli Akhisar Ovası'ndaki ilk iskanın Neolitik Çağ’a kadar gittiği bilinmektedir (Akdeniz 2011a, s. 7; Akdeniz 2014a, s. 22; Erön, Akdeniz, Çekilmez ve Çakan 2018, s. 151-152; French 1969, s. 50-51, 54, 58). Bölgenin erken dönem iskanı konusundaki ilk araştırma D. French tarafından yapılmıştır. D. French, 1959 ve 1960 yılları arasında Balıkesir ve Akhisar bölgelerini kapsayan bir yüzey araştırması çalışması gerçekleştirmiştir. Araştırmanın Akhisar bölümünde bölgenin erken dönem iskanını kanıtlayacak yerleşim yerleri de tespit edilmiştir ${ }^{1}$ (French 1969, s. 47-51). Söz konusu ilk çalışmaların arkasından R. Dinç başkanlığındaki bir ekip tarafından Akhisar ve çevresinde yeni bir yüzey araştırması çalışması yapılmıştır. R. Dinç, Akhisar ve çevresinde gerçekleştirdiği çalışmalar sırasında bölgenin erken dönem iskanını kanıtlayacak buluntuların yanı sıra geç dönem eserlerini de incelemiştir² (Dinç 1996, s. 11-41; Dinç 1997, s. 255-282). Araştırmaların odak noktasını Kulaksızlar Mermer Atölyesi çalışmaları oluşturmaktadır. Kulaksızlar Mermer Atölyesi’nin öneminin fark edilmesinin arkasından T. Takaoğlu atölyenin bulunduğu alanda yeni bir yüzey araştırması çalışması gerçekleştirmiştir (Takaoğlu 2001, s. 157-168). Söz konusu çalışmalar sırasında tespit edilen buluntular 1şığında Kulaksızlar Mermer Atölyesi bilim dünyasına tanıtılmıştır (Takaoğlu 2000; Takaoğlu 2002, s. 71-93; Takaoğlu 2005; Takaoğlu 2011, s. 161-162). T.

1 French söz konusu yüzey araştırması çalışmalarında Akhisar civarındaki Akhisar, Akırbey Çiftlik, Kennez I, Kennez II, Mecidiye, Moralı I, Rahmiye I, Rahmiye II, Sazköy ve Süleymanlı höyüğü olarak adlandırdığı yerleşimlerdeki erken dönem seramiklerini ve kalıntılarını değerlendirmiştir.

21994 yılı yüzey araştırması çalışmalarını Kulaksızlar ve Harmandalı Köyü sınırları içerisindeki arazide gerçekleştirmiştir. Dinç, Kulaksızlar Köyü yakınlarındaki “Mermer İdol Atölyesi” olarak tanımlanan alanın malzemesinin Harmandalı Dağı'ndan getirildiğini ifade etmektedir. 1995 yılı çalışmaları ise daha geniş bir alanda yapılmıştır. Kulaksız Mermer Atölyesi’nin yanı sıra Akhisar-Kırkağaç-Saruhanlı arasında kalan arazi de incelenmiştir. 
Takaoğlu, Kulaksızlar Mermer Atölyesi'nin yanı sıra Akhisar çevresindeki erken dönem yerleşimlerinin bazılarını da yayınlamıştır (Takaoğlu 2004, s. 743-751; Takaoğlu 2017, s. 1-13).

C. Roosevelt Lydia Bölgesi’ndeki Lydia ve Pers yerleşimleri üzerine gerçekleştirdiği çalışmalar sırasında Akhisar Ovası ve çevresini de incelemiştir. Söz konusu çalışmalarda Demir Çağı ve sonrasına yoğunlaşılmakla birlikte bölgenin erken dönem iskanı konusunda bilgilere de yer verilmiştir. C. Roosevelt çalışmalarında Karahöyük Dağı'ndan “Karayunt Dağı" olarak bahsetmektedir (Roosevelt 2017, s. 86, 292-293).

Son yıllarda Akhisar ve çevresinin erken dönem iskanı konusunda en kapsamlı çalışmalar hiç kuşkusuz E. Akdeniz tarafından yapılmaktadır. E. Akdeniz ilk olarak bölgede 2007-2009 yılları arasında yüzey araştırması çalışmaları gerçekleştirmiştir ${ }^{3}$ (Akdeniz 2009, s. 255266; Akdeniz 2010a, s. 153-174; Akdeniz 2012, s. 51-68). Bölgenin erken dönem iskanı konusunda çok önemli tespitlerin yapıldı̆̆ dünyasına tanıtılmıştır (Akdeniz 2010b, s. 65-83; Akdeniz 2011b; Akdeniz 2013a, s. 1-26; Akdeniz 2018, s. 336-359).

E. Akdeniz, söz konusu yüzey araştırması çalışmalarının tamamlanmasının arkasından 2011 yılında Akhisar, Thyateira antik kenti ve Hastane Höyüğ̈̈nde kazı çalışmalarına başlamıştır (Akdeniz 2013b, s. 429-444; Akdeniz 2014b, s. 124-139; Akdeniz, Şahin ve Erön 2015, s. 121-138; Akdeniz ve Erön 2016, s. 81-94; Akdeniz ve Erön 2017a, s. 403416; Akdeniz, Erön ve Kaya 2018, s. 1-14). Kazı çalışmaları yoğun olarak Hastane Höyüğü alanında devam etmektedir. Söz konusu kazı çalışmaları sırasında bölgenin erken dönem iskanına katkı sağlayan buluntuların ${ }^{4}$ yanı sıra Lydia kültürüne ${ }^{5}$ (Akdeniz ve Erön 2017b, s. 79-92; Çakan 2018) ait kalıntı ve buluntuların ortaya çıkarılmış olması da oldukça önemlidir.

Yukarıda belirtilen araştırmaların tamamlanmasının ardından 2016-20186 yılları arasında ekibimiz tarafından Karahöyük Dağı ve çevresinde yeni bir yüzey araştırması çalışması gerçekleştirilmiştir (Erön ve ark. 2018, s. 147-161; Erön, Akdeniz, Çekilmez, Çakan, Maden ve Kızıl 2019, s. 237-248). Karahöyük Dağı ve çevresindeki iskanı tespit etmek amacıyla

3 Söz konusu yüzey araştırması çalışmaları 2007-2010 yılları arasında Tübitak tarafından desteklenmiştir. "Prehistorik ve Protohistorik Çağlarda Manisa ve Çevresi” başlıklı araştırma projesi (Proje No:107K030) kapsamında bölgede yer alan birçok erken dönem yerleşimi konusunda önemli tespitlerde bulunulmuştur.

4 Hastane Höyüğü’nde 2017 yılında gerçekleştirilen kazı çalışmaları sırasında Geç Neolitik Çağ’a tarihlendirilen seramik parçaları bulunmuştur. Söz konusu seramikler tabaka buluntusu değildir. Fakat höyükte Geç Neolitik Çağ iskanını kanıtlaması açısından oldukça önemlidirler.

5 Hastane Höyüğü'nde 2015 kazı sezonunda İ-36/d plankaresinde gerçekleştirilen kazı çalışmaları sırasında çok sayıda kırık Lydia seramiği parçası ortaya çıkarılmıştır. Söz konusu seramik parçalarının bir tabaka buluntusu olması oldukça önemlidir. Hastane Höyüğü alanının Lydia Dönemi içerisinde iskan gördüğünü kanıtlayan seramik parçalarının benzerleri 2016 ve 2017 yılı kazı sezonlarında da bulunmuştur.

62016 yılı çalışmaları 1-10 Eylül, 2017 yılı çalışmaları 28 Haziran-10 Temmuz, 2018 yılı çalışmaları ise 2-13 Temmuz tarihleri arasında gerçekleştirilmiştir. 
başlanılan çalışmalar sırasında çok önemli sonuçlara ulaşılmıştır. Oldukça stratejik bir noktada yer alan Karahöyük Dağı'nın zirvesi ve çevresinde gerçekleştirilen çalışmalarda eski araştırmalar sırasında tespit edilen höyüklere ek olarak yeni höyük ve yamaç yerleşimlerinin de tespit edilmesi oldukça önemlidir. Ekibimiz tarafından yeni tespit edilen höyüklerden bir tanesi Kocanadas Mevkii olarak bahsedilen alanda yer almaktadır.

\section{Kocanadas Mevkii (Resim 4)}

Kocanadas Mevkii, Karahöyük Dağı'nın güneybatısında yer almaktadır. Kayalıŏlu Mahallesi’nin $5.3 \mathrm{~km}$ güneyinde, Rahmiye Mahallesi'nin $2 \mathrm{~km}$ batısındadır ${ }^{7}$. Höyüğün yer seçiminde kuzeyinde yer alan Karahöyük Dağı'nın konumundan yararlanıldı̆̆ anlaşılmaktadır. Akhisar Ovası'nda sert kuzey rüzgarları oldukça önemlidir. Karahöyük Dağı'nın güneyinde yer alan yerleşimlerin seçiminde söz konusu rüzgardan korunma durumuna dikkat edilmiş olmalıdır. Kocanadas Mevkii'nde yer alan höyük (Resim 5-6) ilk olarak 2017 yılı yüzey araştırma çalışmaları sırasında tespit edilmiştir (Erön ve ark. 2019, s. 241-242). Söz konusu arazinin tarımsal faaliyetler nedeniyle sürüleceği düşüncesiyle 2018 yılı çalışmaları sırasında tekrar incelenmiştir.

Yayvan bir tepe görünümündeki höyüğün kapladığı alan dikkat çekicidir. Höyük kuzeygüney yönünde $196 \mathrm{~m}$, doğu batı yönünde ise $172 \mathrm{~m}$ lik bir alanı kaplamaktadır. Tarımsal faaliyetler nedeniyle höyüğün gerçek yayılım sahasını tespit etmek çok zordur. Söz konusu arazide yer alan bölgenin önemli Neolitik Çağ yerleşimlerinden olan Moralılar Höyüğü'nün8 yaklaşık olarak 200x150 m lik bir alanı kapladığı tespit edilmiştir. Yine Karahöyük Dağı'nın güneyinde, Moralılar ve Rahmiye mahalleleri arasında yer alan Örentepe Höyüğ̈̈9 ise yaklaşık olarak 55x80 m lik bir alanı kaplamaktadır. Söz konusu arazide yer alan Rahmiye II Höyügü'nün ${ }^{10}$ ise 200x150 m lik bir alanı kapladığı tespit edilmiştir. Rahmiye I Höyüğü araştırma sahası içerisinde yer aldığı bilinen fakat günümüzde yeri saptanamayan bir

7 Kocanadas Höyüğü 3851'23" Kuzey, 2746’7” Doğu koordinatlarında yer almaktadır.

8 Moralılar Höyüğ̈̈, Moralılar Mahallesi’nin $1.3 \mathrm{~km}$ güneybatısında yer almaktadır. İlk olarak French tarafindan tespit edilmiştir (French 1969, s. 50). French söz konusu yayında höyügün 150 metre çapında bir alanı kapladığını ifade etmektedir. Tarımsal faaliyetler dikkate alındığında höyüğün kapladığı düşünülen alanın farklılık göstermesi normaldir. Akhisar ve çevresinde Neolitik Çağ yerleşimleri arasında en iyi araştırılan höyüktür. Söz konusu höyük ile ilgili araştırma ve yayınlar için bkz; (Akdeniz 2009, s. 256; Akdeniz 2011, s. 11, Fig. 5; Akdeniz 2013a, s. 8, Foto 27; Dinç 1997, s. 266-267, Res. 19-21; Erön ve ark. 2018, s. 151-152, Res. 6-7; French 1969, s. 50; Lichter 2005, s. 61-63, 66; Takaoğlu 2004, s. 743-751).

9 Örentepe Mevkii olarak adlandırılan arazi üzerinde yer alan höyüklerin isimlendirilmesi bir hayli problemlidir. Söz konusu arazi üzerindeki höyük Akdeniz başkanlığında gerçekleştirilen yüzey araştırması çalışmaları sırasında incelenmiş ve “Örentepe II Höyüğ̈̈” olarak adlandırılmıştır. Örentepe II Höyüğü ile ilgili araştırma ve yayınlar için bkz; (Akdeniz 2010a, s. 154; Erdan 2010, s. 23-24, Res. 7-8, Erön ve ark. 2018, s. 152, Res. 9-10).

10 Rahmiye Mahallesi’nin güneyinde yer alan Rahmiye II Höyüğü’nün bulunduğu arazi yöre halkı tarafından Tosuntepe Mevkii olarak adlandırılmaktadır. Söz konusu höyük ile ilgili araştırma ve yayınlar için bkz; (Akdeniz 2009, s. 257; Erdan 2010, s. 27-28, Res. 13-14; Erön ve ark. 2018, s. 153, Res. 13; French 1969, s. $50)$. 
yerleşimdir. D. French'in bölgede gerçekleştirdiği yüzey araştırması çalışmaları sırasında tespit edilen (French 1969, s. 50) höyüğün yeri günümüzde bilinmemektedir. Rahmiye I Höyüğü'nün tarımsal faaliyetler sebebiyle tahrip edildiği düşünülmektedir (Akdeniz 2009, s. 257, dipnot 9). D. French ilgili yayınında höyüklerin yayılım alanlarını ifade ederken sadece tek bir genişlik ve yüksekliğe yer vermiştir. Söz konusu höyüğün $80 \mathrm{~m}$ genişliğinde bir alana yayıldığını ifade etmiştir. Kocanadas Höyüğü’nün Karahöyük Dağı'nın güneyinde yer alan diğer höyüklerle kıyaslandığında biraz daha geniş bir alanı kapladığı anlaşılmaktadır.

\section{Seramik Buluntuları}

Kocanadas Höyüğü'nde gerçekleştirilen yüzey araştırması çalışmaları sırasında çok sayıda seramik parçası bulunmuştur. Söz konusu arazide seramik buluntuları höyüğün merkezi olarak tanımlayabileceğimiz alanda artış gösterirken, arazinin eteklerine doğru seramik buluntularındaki azalma dikkat çekicidir. Günümüzde tarımsal faaliyetlerin devam ettiği alanda bulunan seramik parçaları, höyügün Geç Neolitik Çağ'dan başlayarak Osmanlı Dönemi'ne kadar iskan gördüğünü kanıtlar niteliktedir ${ }^{11}$.

\section{Geç Neolitik-Erken Kalkolitik Çă̆ Seramikleri (Resim 7)}

Kocanadas Mevkii'nde yer alan höyükte Geç Neolitik-Erken Kalkolitik Çă̆’a tarihleyebileceğimiz seramik buluntularının hamur renkleri gri ile kahverengimsi gri arasında değişmektedir. Eserlerin hamurlarında taşçık, mika, kireç ve kum katkıları dikkat çekmektedir. Söz konusu döneme tarihlendirilen seramik buluntularının kiremit kırmızısı siyah alacalı, kahverengimsi turuncu ve kahverengimsi gri renkte astarlı oldukları tespit edilmiştir. Buluntuların çoğunluğunu gövde parçaları oluşturmaktadır. Bir tane kulp parçası bulunmuştur. Söz konusu kulbun üzerinde iki adet çentik yer almaktadır.

Kocanadas Höyüğü'nde bulunan Geç Neolitik-Erken Kalkolitik Çağ'a tarihlendirilen seramik örneklerinin formları, genelde gövde parçaları olmaları sebebiyle tespit edilememiştir. Manisa ili ve çevresindeki Geç Neolitik Çağ seramik örnekleri incelendiğinde formların çok çeşitli olmadığı, genelde çanak, çömlek ve kaselerden oluştuğu anlaşılmaktadır (Akdeniz 2011a, s. 16). Araştırma sahamız içerisinde yer alan Moralılar (Akdeniz 2011a, s. 25, Fig. 57-63) ve Akhisar (Akdeniz 2011a, s. 25, Fig. 54-56) höyüklerinde benzer gövde yapısına sahip seramik parçalarına rastlanılmıştır.

\section{Son Kalkolitik Çă̆ Seramikleri (Resim 8)}

Son Kalkolitik Çağ’a tarihlendirebileceğimiz seramik buluntularının hamurları kahverengimsi turuncu, bej (kahverengimsi bej), gri ve kahverengimsi gri renklidir. Hamurlarda

11 Kocanadas Höyüğü’nde bulunan erken dönem seramiklerinin tarihlendirilmesinde Prof. Dr. E. Akdeniz'den yardım alınmıştır. Kendisine teşekkürü bir borç bilirim. 
taşcık, kum, kireç ve az miktarda mika katkısı tespit edilmiştir. Yüzeyi perdahlı parçalar vardır. Parçaların kahverengi (koyu kahverengi, kırmızımsı kahverengi) ve siyah renkte astarlı oldukları tespit edilmiştir. Kocanadas Höyüğü’nde bulunan Son Kalkolitik Çağ seramik parçalarının benzerleri Hastane Höyüğü (Akdeniz ve Erön 2017a, s. 407), Kennez Höyüğü (Akdeniz 2011b, s. 18-19), Akhisar Höyük (Akdeniz 2011b, s. 15), Bağçeşme Höyüğü (Akdeniz 2011b, s. 16) ve Erdelli Höyük (Akdeniz 2011b, s. 18) yerleşimlerinde karşımıza çıkmaktadır.

\section{İlk Tunç Çăğ Seramikleri (Resim 9)}

İlk Tunç Çağı'na tarihlendirilen seramik buluntularının hamurlarının gri, koyu gri, siyahımsı gri ve açık kahverengi renklerinde oldukları tespit edilmiştir. Hamurlarda mika, taşcık ve kum katkısı vardır. Söz konusu seramik parçalarından bazılarının yüzeyi perdahlıdır. Seramik buluntularının siyah, siyahımsı gri, koyu gri, kahverengimsi kırmızı, turuncumsu kahverengi ve devetüyümsü turuncu renkte astarları vardır. Söz konusu döneme tarihlendirilen tek bir seramik parçasının astarsız olduğu tespit edilmiştir. Kocanadas Höyügü̈nde bulunan İlk Tunç Çağı'na verilen seramik parçalarının genel olarak çanak ve çömlek formalarına ait olduğu anlaşılmaktadır. Omurgalı çanak parçaları dikkat çekicidir. Benzer örnekler Kennez I (French 1969, s. 48, Fig. 9, no. 11, 28), Kennez II (French 1969, s. 48, Fig. 10, no. 1, 26, 27), Beycesultan (Lloyd ve Mellaart 1962, s. 118, Fig. P. 14, no. 1012, 20-25), Ulucak (Çilingiroğlu, Derin, Abay, Sağlamtimur ve Kayan 2004, Fig. 17, no. 5), Erdelli (Dinç 1991, s. 31, Abb. 3) ve Hastane Höyüğü (Akdeniz ve Erön 2016, s. 83, 85, Çiz. 2 d-e) yerleşimlerinde karşımıza çıkmaktadır.

\section{Orta Tunç Çă̆ Seramikleri (Resim 10)}

Kocanadas Höyüğü'nde Orta Tunç Çağı'na tarihlendirilen seramik parçalarının büyük çoğunluğunu gri mallar oluşturmaktadır. Seramiklerin hamurları gri ve açık gri renklerindedir. Eserlerin büyük çoğunluğunun hamurlarında mika, kum ve ince taneli taşcık katkısı dikkati çeker. Bir tane seramik parçasının hamurunda kireç katkısı saptanmıştır. Parçaların büyük çoğunluğu gri (koyu gri, kahverengimsi gri, açık gri) renkli astar boyalıdır. Bir adet seramik parçasının grimsi kahverengi astar boyası olduğu tespit edilmiştir. Orta Tunç Çă̆ı'na tarihlendirilen seramik parçalarında form özelliklerini tespit edebileceğimiz buluntu sayısındaki artış dikkat çekicidir. Profil veren seramik parçalarının büyük çoğunluğunun çanak formlarına (omurgalı çanak, "S" profilli çanak, sığ çanak, ip delikli çanak) ait olduğu tespit edilmiştir. Çanak parçalarından hafif içe çekik, dik ve eğik ağzı kenarı profiline sahip olan parçalar oldukça dikkat çekicidir. Omurgalı çanak parçaları az da olsa görülmeye devam eder. Kocanadas Höyüğü'nde bulunan ve Orta Tunç Çă̆ı'na tarihlendirilen seramik parçalarının benzerleri Beycesultan (Lloyd ve Mellaart 1965, s. 106, Fig. P.14, 4), Sindirg1 (French 1969, s. 47, Fig. 19.1) ve Hastane Höyüğü (Akdeniz ve ark. 2015, s. 125-126, Res. 5; Akdeniz ve Erön 2016, s. 83, 85, Çiz. 3) yerleşimlerinde karşımıza çıkmaktadır. 


\section{Son Tunç Çăğ Seramikleri (Resim 11)}

Kocanadas Höyüğü'nde Son Tunç Çağı'na tarihlendirilen çok sayıda seramik parçası bulunmuştur. Seramiklerin hamur renkleri kahverengi, devetüyü, gri, kırmızı, turuncu ve pembemsi bej arasında değişmektedir. Kahverengi ve devetüyü hamur rengine sahip olan örnekler çoğunluktadır. Seramiklerin hamurlarında mika, taşcık, kum, ve kireç katkısı gözlemlenmiştir. Az sayıdaki seramik parçasının perdahlı olduğu tespit edilmiştir. Söz konusu seramik parçalarının neredeyse tamamına yakınında astar boya tespit edilmiştir. Eserlerde kahverengi, devetüyü, kırmızı, kahverengimsi turuncu, gri ve krem renginde astar boyanın tercih edildiği anlaşılmaktadır. Son Tunç Çağı'na tarihlendirilen iki adet seramik parçası üzerinde altın yaldızlı krem astar boyası tespit edilmiştir. Söz konusu seramikler arasında altın yaldızlı örneklerin olması oldukça önemlidir ${ }^{12}$.

Seramik parçalarının çanak (dışa eğik ağızlı, omurgalı, sığ, "S" profilli), çömlek, sepet kulplu çömlek, kase, testi, tabak, küp ve yonca ağızlı testi formlarına ait olduğu anlaşılmaktadır. Son Tunç Çağı'na tarihlendirilen seramik parçalarının önemli bir bölümünü çanak formlarına ait parçalar oluşturmaktadır. Çanak örneklerinde dışa eğik, dışa çekik, dışa kalınlaştırılmış, düz, dik ve içe eğik ağız kenarı profiline sahip parçalar tespit edilmiştir. Dışa kalınlaştırılmış ağız kenarı parçaları çoğunluktadır. Çömlek formlarında hafif dışa eğik ve kase formlarında ise dışa sarkıtılmış ağız kenarı profiline sahip parçalar tespit edilmiştir. Kocanadas Höyüğü'nde bulunan Son Tunç Çăğ seramik örneklerinin benzerleri Aphrodisias (Joukowsky 1986a, s. 366, Fig. 308, 8), Beycesultan (Mellaart ve Murray 1995, s. 41, Fig. P. 19, 8,11) ve Hastane Höyüğü (Akdeniz ve ark. 2015, s. 125-126, Res. 6; Akdeniz ve Erön 2016, s. 85, Çiz. 4) yerleşimlerinde karşımıza çıkmaktadır.

\section{Demir Çăgl - Lydia Seramikleri (Resim 12-13)}

Kocanadas Höyügü̈'nün Erken Demir Çağı'nda da iskan gördüğünün en önemli kanıtı seramik buluntularıdır. Çoğunluğu 2018 yılı yüzey araştırması çalışmaları sırasında tespit edilen parçaların kahverengi, turuncu, devetüyü, kırmızı, gri ve bej renklerinde hamurları vardır. Hamurların içerisinde mika, kireç, kum ve taşcık katkısı tespit edilmiştir. Mika katkısı neredeyse her parçada vardır. Kahverengi, kırmızı, devetüyü ve kırmızımsı turuncu renklerinde astar boyaları vardır. Söz konusu döneme tarihlendirilen seramiklerin oinokhoe, skyphos, çanak, tabak, testicik ve testi formlarına ait oldukları anlaşılmıştır.

12 Altın yaldızlı seramik örnekleri Batı Anadolu coğrafyasında İlk Tunç Çağı’ndan başlayarak Demir Çağı içlerine kadar popülerliğini koruduğu anlaşılan özel bir gruptur. Söz konusu seramik örnekleri yayınlarda "Gold Wash Ware", "Mika Zerrecikli Astarlı" ve "Altın Mika Astarlı” gibi değişik isimlerle anılmaktadır. Altın yaldızlı seramik örnekleri için bkz; (Aykurt 2010, s. 11-12; Erkanal, Artzy ve Kouka 2003, s. 429, Res. 8; French 1969, s. 72; Greenewalt 2010b, s. 125, 441, No. 38; Konakçı 2014, s. 64-65). 
Kocanadas Mevkii'nde yer alan höyüğün Lydia Dönemi içerisinde iskan gördüğünün en önemli kanıtı yoğun seramik buluntularıdır. 2017 ve 2018 yıllarında gerçekleştirilen çalışmalarda çok sayıda Lydia seramiği örneği tespit edilmiştir. Seramiklerin hamur renkleri kahverengi, turuncu, devetüyü, kırmızı, bej ve gri arasında değişmektedir. Eserlerin hamurlarında mika, kireç, taşcık ve kum katkısı göze çarpmaktadı1 ${ }^{13}$. Lydia seramiklerinin astar boyalarının kahverengi, kırmızı, turuncu, turuncumsu devetüyü ve turuncumsu krem renklerinde olduğu tespit edilmiştir. Söz konusu seramik parçalarının testi, çanak, tabak, skyphos, küp, testicik, çömlek ve kase gibi formlara ait oldukları saptanmıştır. Tabak parçaları en yoğun grubu oluşturmaktadır.

Lydia seramiğinin kendisine has bir bezeme anlayışının olduğu bilinmektedir. Kocanadas Höyüğü'nde bulunan seramikler incelendiğinde bir tanesinin "Kırmızı Üzerine Siyah” (Black on Red) ${ }^{14}$ tekniğinde yapıldığı tespit edilmiştir. Yapılan araştırmalar sonucunda söz konusu tekniğin Lydia seramiğinde MÖ 9-6. yüzyıllar arasında kullanıldığı bilinmektedir (Gürtekin 1998, s. 40). "Kırmızı Üzerine Siyah” (Black on Red) tekniğinde yapılmış Lydia seramik örnekleri Sardeis (Greenewalt 2010a, s. 109-110, Res. 8-9; Gürtekin 1998, s. 25-26), Ephesos (Brein 1978, s. 726-728; Kerschner 2007, s. 232-234, Taf. 33.3; Kerschner 2008, s. 344-345, Kat.-No. 289-290; Kerschner 2010, s. 254, Res. 3), Smyrna (Gürtekin 1998, s. 46; Kerschner 2010, s. 254, Res. 3), Aphrodisias (Mierse 1986, s. 419), Daskyleion (Gürtekin 1998, s. 46), Gordion (Schaus 1992, s. 152-168) ve Thyateira (Akdeniz ve Erön 2017b, s. 84-85, Res. 4, Çiz. 1; Çakan 2018, s. 39-44) gibi yerleşim yerlerinde tespit edilmiştir.

Kocanadas Höyüğü'nde tespit edilen Lydia seramikleri arasında "Bikrom15" bezeme geleneğine sahip parçalar da bulunmaktadır. Söz konusu parçalardan altı tanesinin bikrom teknikte yapıldığı anlaşılmasına karşın seramiklerin çok küçük olmaları nedeniyle baskın zemin renkleri tespit edilememiştir. Bir seramik parçasının "Beyaz Bikrom" tekniğinde boyandığ1 anlaşılmıştır. Lydia seramiğinde "Beyaz Bikrom" örnekleri genel olarak MÖ 8-6. yüzyıllar arasına tarihlenmektedir (Gürtekin 1998, s. 122). Sardeis (Gürtekin 1998, s. 110), Daskyleion (Gürtekin-Demir 2002, s. 120-121, Fig. 9; Koçak-Yaldır 2009, s. 89-

13 Lydia seramiklerinin neredeyse tamamında mika katkısı göze çarpmaktadır. Yoğun mika katkılı parçalar çoğunluktadır. Katkı malzemeleri arasında mikadan sonra en çok kireç tercih edilmiştir. Kireci taşcık ve kum takip etmektedir.

14 "Kırmızı Üzerine Siyah" (Black on Red) tekniği olarak adlandırılan bezeme anlayışının Anadolu'nun yerel seramik geleneğinin Demir Çağı’ndaki devamı olduğu düşünülmektedir. Görüş için bkz; (Greenewalt 2010a, s. 110, 112).

15 Bikrom bezeme geleneğinin de yine Anadolu'nun yerel seramik geleneğinin devamı olduğu düşünülmektedir. Görüş için bkz; (Greenewalt 2010a, s. 110, 112). Bikrom bezeme anlayışı genel olarak ana zemin renginin üzerinde iki renk kullanılarak yapılan bezemeleri ifade etmek için kullanılmıştır. Lydia seramiğinde bikrom tekniği baskın zemin rengi dikkate alınarak "Beyaz Bikrom" ve Kırmızı Bikrom" olmak üzere ikiye ayrılmaktadır. Lydia seramiğindeki bikrom bezeme tekniğinin genel olarak MÖ 8-6. yüzyıllar arasında kullanıldığı tespit edilmiştir. "Beyaz Bikrom" örnekler genel olarak MÖ 8-6. yüzyıllar arasında, "Kırmızı Bikrom” örnekler ise genel olarak MÖ 7-6. yüzyıllar arasında görülmektedir. 
90) ve Thyateira (Akdeniz ve Erön 2017b, s. 85, Res. 5, Çiz. 2; Çakan 2018, s. 45-46) yerleşimlerinde "Beyaz Bikrom" tekniğinde yapılmış seramik örnekleri bulunmaktadır. Kocanadas Höyüğü'nde bulunan Lydia seramiklerinden iki tanesinin "Kırmızı Bikrom" tekniğinde yapıldığı tespit edilmiştir. "Kırmızı Bikrom” tekniği genel olarak MÖ 7-6. yüzyıllar arasına tarihlenmektedir (Gürtekin 1998, s. 122). Sardeis (Greenewalt 2010a, s. 110, Res. 10; Gürtekin 1998, s. 110-111), Daskyleion (Gürtekin-Demir 2002, s. 121, Fig. 10; Koçak-Yaldır 2009, s. 90-91) ve Thyateira (Akdeniz ve Erön 2017b, s. 85-87, Res. 6-8, Çiz. 3-5; Çakan 2018, s. 46-47) yerleşimlerinde söz konusu bezeme tekniği kullanılarak yapılmış seramik örnekleri saptanmıştır.

Kocanadas Höyüğü'nde yapılan araştırmalar sırasında Lydia seramiğinde "Damarlı Boyama"16 (Streaky Glazed) tekniği olarak adlandırılan bezemeye sahip parçalar da bulunmuştur. Söz konusu teknik MÖ 8. yüzyılın ortalarından itibaren kullanılmaya başlanmıştır (Gürtekin 1998, s. 244). Asıl yoğun kullanımının MÖ 7-6. yüzyıllar arasında olduğu bilinmektedir (Gürtekin-Demir 2002, s. 123). "Damarlı Boyama" tekniği kullanılarak yapılmış Lydia seramiği örnekleri Sardeis (Gürtekin 1998, s. 243), Ephesos (Kerschner 2007, s. 234-235, Taf. 33.1), Daskyleion (Gürtekin-Demir 2002, s. 122-123, Fig. 11-14), Smyrna (Kerschner 2010, s. 254, Res. 3), Börükçü (Gider Büyüközer 2014, s. 121-124) ve Thyateira'da (Akdeniz ve Erön 2017b, s. 88-89, Res. 10-11, Çiz. 7-8; Çakan 2018, s. 49) karşımıza çıkmaktadır.

\section{Hellenistik Dönem Seramikleri}

Kocanadas Höyügü̈’nde yapılan incelemeler sırasında Hellenistik Dönem'e tarihlenen çok fazla sayıda parça bulunamamıştır. Söz konusu döneme ait olduğunu düşündüğümüz bir seramik parçasının hamuru portakalımsı bej renktedir. Hamur içerisinde yoğun mika ve az miktarda kum katkısı tespit edilmiştir. Seramik parçasının siyah bir astarı vardır. Siyah astarlı seramiklerin MÖ 6-4. yüzyıllar arasında tercih edildiği bilinmektedir. Fakat Kocanadas buluntusu parça astar boyasının daha mat olması nedeniyle erken örneklerden ayrılmaktadır. Siyah astar boyanın genel özellikleri dikkate alınarak Hellenistik Dönem’e tarihlendirilmiştir. Seramik parçasının formu tespit edilmemiştir.

Yukarıda değinilen parçanın yanı sıra Geç Hellenistik-Erken Roma Çağ'ı arasına tarihlendirilen iki seramik parçası da anılmaya değerdir. Portakalımsı bej hamur rengine sahip olan eserlerin hamurlarında mika katkısı gözlemlenmiştir. Kırmızı renkli astara sahip olan parçaların formu tespit edilememiştir.

16 "Damarlı Boyama" tekniğinde kabın yüzeyine demiroksit içerikli bir boya sürülmektedir. Fırınlamanın ardından firça üzerindeki kil miktarına bağlı olarak kabın yüzeyindeki boyalar kahverengi, kırmızı ve siyah arasında değişen tonlarda karşımıza çıkmaktadır. Lydia seramiğinin basit, fakat en kolay tanınabilir bezeme tekniğidir. 


\section{Roma Çă̆ Seramikleri (Resim 14)}

Kocanadas Höyüğü'nde yapılan incelemeler sonucunda Roma Çağı'nda seramik buluntularının sayısının tekrar arttığı tespit edilmiştir. Söz konusu seramiklerin hamurlarının kahverengi, turuncu, bej, gri ve turuncumsu devetüyü renklerinde olduğu tespit edilmiştir. Seramik parçalarının hamurlarında mika, taşçık, kum ve kireç katkısı gözlemlenmektedir. Roma Çă̆ı'na tarihlendirilen seramiklerde kahverengi, devetüyü, turuncumsu bej, kırmızı, gri ve krem renklerde astar boyası kullanıldığı anlaşılmıştır. Seramik parçaları çömlek, çanak, testi ve testicik gibi formlara aittir. Söz konusu seramikler genel olarak MS 2-3. yüzy1l aralığına tarihlenebilir. Çömlek örneklerinin form olarak benzerleri Ephesos (Ladstätter 2005, s. 342, Taf.196, K 771; Mitsopoulos Leon 1991, s. 134, K 25, Taf 189), Didyma (Wintermeyer 2004, s. 90, Abb. 640), Sardeis (Crawford 1990, s. 23, Fig. 50) ve Patara (Korkut 2007, s. 152, Nr. 9) gibi yerleşimlerde karşımıza çıkmaktadır. Diğer formlara ait seramik parçaları çok küçük olduğu için benzerlerini saptamak oldukça zordur.

Geç Roma Çağı'na tarihlendirilen seramikler ise turuncu, kahverengi, kırmızı, gri ve devetüyü renginde hamurlara sahiptirler. Hamurlarda mika, taşcık, kum ve kireç katkısı tespit edilmiştir. Söz konusu döneme tarihlendirilen seramiklerin bej, turuncu, devetüyü, turuncumsu kahverengi ve kiremit kırmızısı renklerinde astar boyaları vardır. Seramik parçalarının büyük çoğunluğunun testi formuna ait olduğu tespit edilmiştir. Testi parçalarının benzer örnekleri Sardeis (Crawford 1990, s. 30, Fig. 92) ve Tralleis (Erön 2013, s. 145146, Kat. No. 169) yerleşimlerinde karşımıza çıkmaktadır. Söz konusu eserler MS 5. yüzyıla tarihlendirilmiştir.

\section{Bizans ve Osmanlı Seramikleri (Resim. 15)}

Kocanadas Höyüğü’nün Bizans ve Osmanlı dönemlerinde de iskan gördüğü seramik buluntuları sayesinde anlaşılmaktadır. Söz konusu dönemlerde seramik buluntusu sayısı daha önceki dönemlere kıyasla daha azdır. Kahverengi, gri, kiremit kırmızısı ve portakalımsı bej renklerinde hamur rengine sahiptirler. Hamurlarda kireç, kum, taşcık ve mika katkısı tespit edilmiştir. Mika katkısı erken dönemlere kıyasla daha azdır. Astar rengi olarak en çok yeşil sırın (koyu yeşil) tercih edildiği anlaşılmaktadır. Yeşil sırın yanı sıra bir parça üzerinde sarı alacalı sır kullanılmıştır. Söz konusu sırlı örneklerin yanı sıra kırmızı, kahverengi, portakalımsı bej ve devetüyü renginde astara sahip parçalara da rastlanılmıştır. Seramik parçalarının küp, çömlek, testi, tabak ve çanak formalarına ait olduğu tespit edilmiştir.

\section{Küçük Buluntular}

Kocanadas Höyüğü'nde seramik örneklerinin yanı sıra az sayıda idol, çakmaktaşı, öğütme taşı ve perdah taşı da bulunmuştur. Küçük buluntular arasında yer alan idoller höyüğün tarihlendirilme çalışmaları açısından oldukça önemlidir. 


\section{İdoller}

Kocanadas Höyüğü'nde 2017 yılı yüzey araştırması çalışmaları sırasında taştan yapılmış bir idol17 bulunmuştur (Resim 16). Gri renkli taştan yapılmış olan eser sağlam durumdadır. İdolün yüzeyinde yer yer patina izleri görülmektedir. Yassı bir gövde yapısına sahip olan eserin her iki yüzü de oldukça iyi bir şekilde düzeltilmiştir. "Troia Tipi İdol18" grubu içerisine ait olduğunu düşündüğümüz eser bazı yayınlarda gövde yapısının " 8 " rakamına benzemesi nedeniyle "8 Formlu İdol" olarak da adlandırılmaktadır (Joukowsky 1986a, s. 212). Kocanadas buluntusu idol örneğinin benzerleri Troia ${ }^{19}$ (Blegen ve ark. 1950, s. 27-28, Fig. 127, Type 3G, Fig. 360, 35-444), Kulaksılar20 (Dinç 1997, s. 262, Res. 12), Aphrodisias $^{21}$ (Joukowsky 1986a, s. 212, Fig. 224-230; Joukowsky 1986b, s. 623, Fig. 449, No 14), Karataş-Semayük (Mellink 1967, Plate 77, Fig. 15), Karahisar 22 (Akdeniz 2002, s. 11-12, 14, 18, Katalog No 12) ve Seyitömer ${ }^{23}$ (Bilgen A. N., Bilgen Z. ve Çırakoğlu 2015, s. 183, Fig. 193b) yerleşimlerinde karşımıza çıkmaktadır. Kocanadas Höyüğü'nde bulunan taş idol, benzer örnekler yardımıyla İlk Tunç Çağı II’ye verilebilir.

Kocanadas Höyüğü’ndeki dinsel inanışlar konusunda bilgi verebilecek pişmiş topraktan yapılmış bir idol24 ise 2018 yılı yüzey araştırması çalışmaları sırasında bulunmuştur (Resim 17). Pembemsi kahverengi hamur rengine sahip olan eserin hamuru iyi arındırılmıştır. Hamurun içerisinde az miktarda kireç ve mika katkısı göze çarpmaktadır. İyi derecede fırınlandığı anlaşılan eserin yüzeyinin perdahlı olduğu düşünülmektedir. Boyun kısmından aşağısı kırık olan eserin yüzeyinde yer yer tahribat izleri gözlenmiştir. Asimetrik bir yüz yapısına sahip olan idolün baş kısmı oval formludur. Alın kısmı geniştir, yüz yapısı çeneye doğru daralmaktadır. Eserin gözleri alnına yakın bir şekilde yapılmıştır. Kabartma şeklinde verilmeye çalışılan gözler birbirilerinden oldukça uzaktadır. Figürün gözleri arasında alnının ortasına yakın bir noktada kabartma şeklinde yapılmış üçüncü bir çıkıntı daha dikkati çekmektedir. Burun, yüzün diğer bölümlerine oranla çok daha büyük işlenmiştir. Asimetrik bir şekilde figürün sol gözüne doğru uzanmaktadır. Figürün ağız bölümü ise yine kabartma olarak hafif sağa kayık bir şekilde verilmeye çalışılmıştır. Kocanadas Höyüğü’nde bulunan pişmiş toprak idolün çok yakın bir benzeri tespit edilememiştir. İlk Tunç Çağı II'ye tarihlendirilen Bademağacı (Bilgi 2012, s. 215, Res. 533) ve İkiztepe (Bilgi 2012, s. 158,

17 Taş idolün ölçüleri; Yükseklik: $4 \mathrm{~cm}$, Kalınlık: $0.7 \mathrm{~cm}$, Üst Genişlik: $2.3 \mathrm{~cm}$, Alt Genişlik:3.1 cm.

18 İdol örnekleri ismini ilk bulundukları yer olan Troia'dan almaktadır. Troia' da gerçekleştirilen kazı çalışmaları sırasında söz konusu idollerin Troia I tabakasından başlayarak Troia II ve Troia IV tabalarında görüldüğü tespit edilmiştir. Söz konusu örnekler için bkz; (Blegen, Caskey, Rawson ve Sperling 1950, s. 27-28, Fig. 127, Type 3G).

19 Makale içerisinde incelenen idolün benzer bir örneği Troia II tabakasında bulunmuştur.

20 R. Dinç söz konusu idolü Troia II tipi idol olarak adlandırmıştır.

21 Joukowsky söz konusu idol örneklerini Tunç Çağ 4 ve Orta Tunç Çağı'na tarihlemiştir.

22 Karahisar Höyük buluntusu benzer örnek E. Akdeniz tarafından İlk Tunç Çağı II'ye tarihlendirilmiştir.

23 Benzer bir Seyitömer buluntusu idol örneği İlk Tunç Çağı'na tarihlendirilmiştir.

24 Pişmiş toprak idolün ölçüleri; Korunan Yükseklik: 4 cm, Kalınlık: 2.6 cm, Genişlik: 4.4 cm. 
Res. 352) yerleşimlerinde bulunan örnekler kafa yapılarının biçimiyle Kocanadas idolünü hatırlatmaktadır.

\section{Çakmaktaşı, Öğütme Taşı ve Perdah Taşları}

Kocanadas Mevkii'nde yer alan höyükte yapılan yüzey araştırması çalışmaları sırasında bulunan çakmaktaşı, öğütme taşı ve perdah taşları anılmaya değerdir. İşlenmemiş çakmaktaşı (Resim 18) buluntularının yanında çakmaktaşından alet (Resim 19) parçalarının bulunması oldukça önemlidir. Perdah taşı ve öğütme taşı örnekleri (Resim 20) höyükteki yaşamı anlamamıza olanak sağlamaktadır. Öğütme taşları höyük ve çevresinde tarımsal faaliyetleri kanıtlaması açısından oldukça önemlidir. Perdah taşları ise seramik üretiminin bir kanıtıdır. Söz konusu buluntular höyüğün olasılıkla Tunç Çağı evrelerinde kullanılmış olmalıdır.

\section{Sonuç}

Kocanadas Mevkii'nde yer alan höyük Karahöyük Dağı'nın güneydoğusunda yer almaktadır. 2017-2018 yılı yüzey araştırması çalışmaları sonucunda höyüğün Geç Neolitik Çă̆’ dan başlayarak Osmanlı Dönemi’nin sonuna kadar iskan gördüğü buluntular ışı̆̆ında anlaşılmaktadır. Geçmiş yıllarda Manisa ilinde gerçekleştirilen yüzey araştırması çalışmaları sonucunda 10 merkezde Neolitik Çağ buluntularına rastlanılmıştır (Akdeniz 2011a, s. 26). Akhisar, Hastane Höyüğünde 2017 yılında gerçekleştirilen kazı çalışmaları sırasında bulunan Geç Neolitik seramik parçaları sonucunda bu sayı 11'e yükselmiştir. Geç Neolitik Çağ buluntusu veren merkezlerin önemli bir bölümü Akhisar ilçesi ve güneyinde karşımıza çıkmaktadır. Yüzey araştırma sahamız içerisinde kalan arazi üzerinde yer alan Akhisar ve Moralılar höyüklerinde Neolitik Çağ buluntularının varlığı geçmiş yıllarda yapılan araştırmalar 1şığında bilinmektedir. Kocanadas Höyüğü’nde Geç Neolitik Çağ’a tarihlendirilen seramik buluntularının saptanması Karahöyük Dağı ve çevresinin erken dönemlerde yoğun bir şekilde iskan gördüğünü kanıtlamaktadı225. Söz konusu Geç Neolitik Çağ yerleşimlerinin birbirleriyle bağlantılı olması akla yatkındır (Resim 4). Hastane HöyüğüAkhisar Höyük-Moralılar Höyük-Kocanadas Höyüğü arasında ulaşımı sağlayan basit bir yol olması gerekmektedir ${ }^{26}$.

Karahöyük Dağı'nın güney eteklerinin yerleşim yeri olarak tercih edilmesi oldukça mantıklıdır. Günümüzde Akhisar ve çevresi özellikle kış aylarında sert kuzey rüzgarlarından oldukça etkilenmektedir. Geç Neolitik Çağ içerisinde bu durum olasılıkla çok daha önemlidir. Karahöyük Dağı'nın güney etekleri sert kuzey rüzgarlarından korunmak için oldukça uygun

25 Söz konusu Neolitik Çağ yerleşimlerinden Akhisar Höyük Karahöyük Dağı'nın doğusunda, Moralılar Höyük ve Kocanadas Mevkii'nde yer alan höyük ise güneyinde yer almaktadır.

26 Akhisar ilçe merkezi ve Karahöyük Dağ1 çevresindeki Geç Neolitik Çağ buluntu merkezleri incelendiğinde Hastane Höyüğü-Akhisar Höyük arası mesafenin 3.20 km, Akhisar Höyük-Moralılar Höyük arası mesafenin 5.50 km, Moralılar Höyük-Kocanadas Höyüğü arası mesafenin 5.50 km olduğu tespit edilmiştir. 
bir alandır. Ayrıca Neolitik Çağ yerleşimlerinin seçiminde su kaynaklarına yakın alanların tercih edildiği bilinmektedir. Karahöyük Dağı'nın güneyinde yer aldığı bilinen fakat yakın zamanda kurutulmuş olan Yemişli Gölü’nün varlığı bu açıdan oldukça önemlidir. Moralılar Höyük ve Kocanadas Mevkii'nde yer alan höyük arasında kaldığı anlaşılan göl Geç Neolitik Çă̆'dan başlayarak her iki yerleşime de hayat vermiş olmalıdır.

İç Batı Anadolu Bölgesi olarak adlandırabileceğimiz alandaki Geç Neolitik Çă̆ iskanın MÖ 7. Binyılın ortaları veya sonlarında başladığı düşünülmektedir (Roosevelt 2010, s. 44)27. Söz konusu yerleşimlerin kökenleri hala tartışmalıdır. Geç Neolitik Çağ yerleşimlerindeki halkın Göller Yöresi ve başka bir yerlerden göç ederek geldikleri fikri üzerinde durulmaktadır. Fakat bu yerleşimlerin kökenini aynı yerde yaşamış olan daha erken kültürlerde aramamız gerektiğini savunan görüşler de vardır (Roosevelt 2010, s. 44).

Kocanadas Höyüğü’nde bulunan seramik ve küçük buluntular 1şığında iskanın Geç Neolitik ve Erken Kalkolitik Çağ arasında çok yoğun olmadığı anlaşılmaktadır. Seramik parçalarının benzerlerine Moralılar ve Akhisar höyüklerinde rastlanılmıştır. Yüzey araştırması sahası içerisinde kalan Moralılar Höyük ile kıyaslandığında erken dönem seramik buluntularının sayısı bir hayli azdır. Höyükte Orta Kalkolitik Çağ'a tarihlendirilen herhangi bir seramik parçası bulunamamıştır ${ }^{28}$. Son Kalkolitik Çağ tarihlendirilen seramik örneklerinin benzerleri Hastane Höyüğü, Akhisar Höyük, Bağçeşme Höyüğü ve Erdelli Höyük yerleşimlerinde karşımıza çıkmaktadır. İlk Tunç Çağı'nda höyükte iskanı kanıtlayacak seramik ve küçük buluntular saptanmıştır. Söz konusu döneme tarihlendirilen omurgalı çanak parçalarının benzerlerine Kennez I, Kennez II, Beycesultan, Ulucak ve Hastane Höyüğü yerleşimlerinde rastlanılmıştır. Orta Tunç Çă̆ı' na tarihlendirilen buluntuların sayısındaki artış dikkat çekicidir. Seramik buluntularının büyük çoğunluğu gri renkli astar boyalıdır. Beycesultan, Sındırgı ve Hastane Höyüğü yerleşimlerinde benzer örnekler bulunmaktadır. Son Tunç Çağı içerisinde höyükteki iskanın güçlü bir şekilde devam ettiği anlaşılmaktadır. Buluntu sayısı bir hayli artmıştır. Söz konusu döneme tarihlendirilen seramik örneklerinin benzerlerine Aphrodisias, Beycesultan ve Hastane Höyüğü yerleşimlerinde rastlanılmıştır. Demir Çağı içerisinde ise yerleşimin önemini hala koruduğu anlaşılmaktadır. MÖ 8-6 yüzyıllar arasına verebileceğimiz Lydia seramiği parçalarının sayısı dikkat çekicidir. Bölgenin yerel kimliğini yansıtan Lydia seramiklerinin benzerleri başta Sardeis olmak üzere Thyateira, Ephesos, Smyrna, Aphrodisias ve Daskyleion gibi dönemin önemli merkezlerinde karşımıza çıkmaktadır. Lydia kültürünün yerel niteliğini ifade ettiğini düşündüğümüz seramik örneklerinin yanında ithal seramik parçalarının saptanmaması oldukça dikkat çekicidir. Kocanadas Höyüğü’nde MÖ 5-4. yüzyıl arasına tarihlenen seramik ve küçük buluntu saptanamamıştır. Bölgede yer alan diğer höyük

27 Küçük ölçekli köylerde yerleşik hayata geçişin ve tarıma dayalı hayatın aynı anda başladığı düşünülmektedir.

28 İç Batı Anadolu coğrafyasında Orta Kalkolitik Çağ iskanında bir boşluk olduğu bilinmektedir. Kocanadas Höyüğü'nde Orta Kalkolitik Çağ seramiklerinin bulunmaması bu açıdan sürpriz değildir. 
ve yerleşimlerde de söz konusu dönemde bir boşluk olduğu anlaşılmaktadır. Hellenistik, Roma, Bizans ve Osmanlı dönemlerine tarihlenen buluntular 1şı̆̆ında höyükte geç dönemde iskanda bir azalma olduğu düşünülebilir. Kocanadas Höyüğü seramik buluntuları genel olarak yerel üretim özellikleri göstermektedir.

Sonuç olarak Kocanadas Höyüğü’nde Geç Neolitik Çă̆’a tarihlendirilen seramik buluntularına rastlanılması oldukça önemlidir. Seramik buluntuları 1şı̆̆ında höyükte Orta Tunç Çağı, Son Tunç Çağı ve Orta Lydia Dönemi²9 olarak adlandırılan (MÖ 8-6 yüzyıl) Demir Çağı içerisinde iskanın diğer dönemlere oranla daha güçlü olduğu anlaşılmaktadır. Söz konusu dönemlerin ardından höyükte yaşamın devam ettiği anlaşılmaktadır. Fakat buluntu sayısı önceki dönemlere kıyasla bir hayli azalmıştır.

\section{Kisaltmalar}

CAST : Araştırma Sonuçları Toplantısı

KST : Kazı Sonuçları Toplantısı

\section{Kaynakça}

Akdeniz, E. (2002). Erken Tunç Çağı'na Ait Bir Grup İdol. Anadolu Araştırmaları, 16, 9-18.

Akdeniz, E. (2009). 2007 Yllında Manisa İli ve İlçelerinde Yürütülen Prehistorik-Protohistorik Yüzey Araştırmaları. Araştırma Sonuçları Toplantısı, 26(2) içinde (s. 255-266). Ankara:

Akdeniz,E. (2010a). 2008Yılında Manisa İli ve İlçelerinde Yürütülen Prehistorik-Protohistorik Yüzey Araştırmaları. Araşstrma Sonuçları Toplantısı: 27(1) içinde (s. 153-174). Ankara: İsmail Aygül Ofset Matbaacıllk.

Akdeniz, E. (2010b). Kulaksızlar Atölyesinde Kilya Tipi Figürin Üretimi. OLBA, XVIII, 65-83.

Akdeniz, E. (2011a). Neolitik Çă̆'da Manisa Yöresi. OLBA, XIX, 1-46.

Akdeniz, E. (2011b). Tarih Öncesinden İlk Demir Çağı'na Manisa. Akhisar: Esin Ofset Matbaac1lık.

Akdeniz, E. (2012). 2010 Yılında Manisa İli ve İlçelerinde Yürütülen Prehistorik-Protohistorik Yüzey Araştırmaları. Araştırma Sonuçları Toplantısı: 29(1) içinde (s. 51-68). Ankara: İsmail Aygül Ofset Matbaacilık.

Akdeniz, E. (2013a). Manisa Yöresindeki Prehistorik-Protohistorik Buluntu Merkezlerinin Dönemsel ve Coğrafi Dağılımları. Akdeniz Sanat Dergisi 3(6), 1-26.

Akdeniz, E. (2013b). 2011 Yılı Akhisar-Thyateira Kazıları. Kazı Sonuçları Toplantısı: 34(2) içinde (s. 429444). Ankara: Pegasus Görsel İletişim Hizmetleri.

29 Lydia Krallı̆̆ı'’nın Demir Çağ kronolojisi içerisinde olan bölümü, söz konusu kültür üzerine çalışmalar yapan araştırmacılar ve özellikle Roosevelt tarafından genel olarak Erken Lydia/Erken Demir Çağı (MÖ 1200-700), Orta Lydia (MÖ 700-546) ve Geç Lydia/Akamenid (MÖ 546-334) dönemleri olmak üzere üçe ayrılmaktadır. Söz konusu krallığın bölgesel bir güç olmasından yola çıkarak özel bir kronoloji önerisinin getirilmesi oldukça mantıklıdır. Kronoloji önerisi için bkz; (Roosevelt 2017, s. 34). 
Akdeniz, E. (2014a). Kuzey Lydia'daki Thyateira’nın Erken Dönem Yerleşimi:Hastane Höyüğü Kazısı. $T \ddot{U} B A-A R, 15,21-45$.

Akdeniz, E. (2014b). 2012 Yılında Thyateira Antik Kenti ve Hastane Höyüğünde Gerçekleştirilen Arkeolojik Çalışmalar. Kazı Sonuçları Toplantısı, 35(2) içinde (s. 124-139). Muğla: Muğla Sıtkı Koçman Üniversitesi Basımevi.

Akdeniz, E. (2018). İlk Tunç Çağı'nda Manisa Yöresi'nde Yerleşim Dokusu. Adnan Menderes Üniversitesi Sosyal Bilimler Enstitüsü Dergisi, 5(1), 336- 359.

Akdeniz, E., Şahin, M. K. ve Erön, A. (2015). 2013 Y1lı Akhisar-Thyateira Antik Kenti ve Hastane Höyüğü Kazısı. Kazı Sonuçları Toplantısı, 36(2) içinde (s. 121-138). Ankara: İsmail Aygül Ofset Matbaacılık.

Akdeniz, E. ve Erön, A. (2016). 2014 Yılı Akhisar-Thyateira Antik Kenti ve Hastane Höyüğü Kazısı. Kazı Sonuçları Toplantısı, 37(2) içinde (s. 81-94). Ankara: İsmail Aygül Ofset Matbaacılık.

Akdeniz, E. ve Erön, A. (2017a). 2015 Yılı Akhisar-Thyateira Antik Kenti ve Hastane Höyüğü Kazısı. Kazı Sonuçları Toplantısı, 38(2) içinde (s. 403-416). Ankara: İsmail Aygül Ofset Matbaacılık.

Akdeniz, E. ve Erön, A. (2017b). Lydia Kültürünün Kuzey Lydia’daki İzleri: Thyateira-Hastane Höyügü Kazıları'nda Bulunan Lydia Seramikleri. $T \ddot{U} B A-A R, 20,79-92$.

Akdeniz, E., Erön, A. ve Kaya, Y. S. (2018). 2016 Y1lı Akhisar-Thyateira Antik Kenti ve Hastane Höyüğ̈̈ Kazısı. Kazı Sonuçları Toplantısı, 39(2) içinde (s. 1-14). Bursa: Bursa Büyükşehir Belediyesi Matbaa Tesisleri.

Aykurt, A. (2010). İzmir Bölgesi Orta Tunç Çağ1 Seramiği. Belleten, LXXIV (269), 1-69.

Bilgen, A. N., Bilgen, Z. ve Çırakoğlu, S. (2015). Erken Tunç Çağı Yerleşimi (V. Tabaka). A. N. Bilgen (Ed.), Seyitömer Höyük I içinde (s. 119-186). İstanbul: Arkeoloji ve Sanat Yayınları.

Bilgi, Ö. (2012). Anadolu’da İnsan Görüntüleri. Klasik Çă̆ Öncesi. İstanbul: Aygaz Yayınevi.

Blegen, C., Caskey, J. L., Rawson, M.,\& Sperling, J. (1950). Troy Vol. I, General Introduction, The First and Second Settlements. Princeton: Princeton University Press.

Brein, F. (1978). Geometrisch Dekorierte Keramik aus Ephesos. E. Akurgal (Ed.), The Proceedings of the Xth International Congress of Classical Archaeology, Vol. II, içinde (s. 721-728). Ankara: Türk Tarih Kurumu Basimevi.

Crawford, J. S. (1990). The Byzantine Shop at Sardis. Archaeological Exploration of Sardis. Cambridge: Harvard University Press.

Çakan, M. S. (2018). Hastane Höyüğü Kazılarında Ele Geçen Lydia Seramikleri Işı̆̆ında M.Ö. 8-6. Yüzyıllar Arasında Thyateira Antik Kenti. (Yüksek Lisans Tezi). Adnan Menderes Üniversitesi Sosyal Bilimler Enstitüsü, Aydın.

Dinç, R. (1991). Erdelli Höyük und die Bedeutung seiner Funde für die bronzezeitliche Geschichte des Manisa-Akhisar-Gebietes. Istanbuler Mitteilungen, 41, 25-38.

Dinç, R. (1996). 1994 Yılı Akhisar-Kulaksızlar Mermer İdol Atölyesi Yüzey Araştırması. Araştırma Sonuçları Toplantısı, 13(2) içinde (s. 11-41). Ankara: T.C. Kültür Bakanlığı Milli Kütüphane Basımevi.

Dinç, R. (1997). Kulaksızlar Mermer İdol Atölyesi ve Çevre Araştırmaları. Araştırma Sonuçları Toplantısı, 14(2) içinde (s. 255-282). Ankara: Kültür Bakanlığ Milli Kütüphane Basımevi.

Erdan, E. (2010). Kum Çayı Vadisi ve Yakın Çevresinde İlk Tunç Çă̆ Yerleşim Dokusu. (Yüksek Lisans Tezi). Adnan Menderes Üniversitesi Sosyal Bilimler Enstitüsü, Aydın.

Erkanal, H., Artzy, M. ve Kouka, O. (2003). 2001 Yılı Liman Tepe Kazıları. Kazı Sonuçları Toplantısı, 24(1) içinde (s. 423-436). Ankara: Kültür Bakanlığı Dösimm Basımevi. 
Erön, A. (2013). Tralleis Hamam-Gymnasion Kompleksi Seramikleri. (Doktora Tezi). Adnan Menderes Üniversitesi Sosyal Bilimler Enstitüsü, Aydın.

Erön, A., Akdeniz, E., Çekilmez, M. ve Çakan, M. S. (2018). 2016 Y1lı Karahöyük Dağı Arkeolojik Yüzey Araştırması Çalışmaları. Araştırma Sonuçları Toplantısı, 35(1) içinde (s. 147-161). Bursa: Bursa Büyükşehir Belediyesi Matbaa Tesisleri.

Erön, A., Akdeniz, E., Çekilmez, M., Çakan, M. S., Maden, E. ve Kızıl, S. (2019). 2017 Y1l1 Akhisar Karahöyük Dağı Yüzey Araştırması Çalışmaları. Araştırma Sonuçları Toplantısı, 36(1) içinde (s. 237248). Çanakkale

French, D. H. (1969). Prehistoric Sites in Northwest Anatolia II. The Balıkesır and Akhisar/Manisa Areas. Anatolian Studies, 19, 41-98.

Gider Büyüközer, Z. (2014). Börükçü Nekropol Alanından Bir Arkaik Mezar. TÜBA-AR, 17, 111-128.

Greenewalt, C. H. (2010a). Lidya'da Çömlekçilik/Lydian Pottery. N. D. Cahill (Ed.), Lidyalılar ve Dünyalarl/ The Lydians and Their World içinde (s. 107-124). İstanbul: Yapı Kredi Yayınları.

Greenewalt, C. H. (2010b). Afiyet Olsun!. N. D. Cahill (Ed.), Lidyalılar ve Dünyalarl/The Lydians and Their World içinde (s. 125-133). İstanbul: Yapı Kredi Yayınları.

Gürtekin, R. G. (1998). Lydia Seramiğindeki Yabancı Etkiler. (Doktora Tezi). Ege Üniversitesi Sosyal Bilimler Enstitüsü, İzmir.

Gürtekin-Demir, R. G. (2002). Lydian Painted Pottery at Daskyleion. Anatolian Studies, 52, 111-143.

Joukowsky, M. S. (1986a). Prehistoric Aphrodisias. An Account of the Excavations and Artifact Studies Vol. I. Louvain: Brown University Press.

Joukowsky, M. S. (1986b). Prehistoric Aphrodisias. An Account of the Excavations and Artifact Studies Vol. II. Louvain: Brown University Press.

Kerschner, M. (2007). Das Keramikbild von Ephesos im 7. Und 6. Jh. V. Chr. J. Cobet ve ark. (Ed.), Milesische Forschungen: Band 5. Frühes Ionien Eine Bestandsaufnahme içinde (s. 221-245). Mainz am Rhein: Philipp von Zabern.

Kerschner, M. (2008). Artemis Kutsal Alanı’nda Bulunan Pişmiş Toprak Kaplar. W. Seipel (ed.), Efes Artemisionu. Bir Tanrıçanın Kutsal Mekanı içinde (s. 331-345). Viyana: Phoibos Yayınevi.

Kerschner, M. (2010). Lidyalıların Komşuları İyonyalılar ve Aiolia'lılar/The Lydians and their Ionian Aiolian Neighbours. N. D. Cahill (Ed.), Lidyalılar ve Dünyalarl/The Lydians and Their World içinde (s. 247265). İstanbul: Yapı Kredi Yayınları.

Koçak-Yaldır, A. (2009). İ.Ö. Yedinci ve Altıncı Yüzyıllarda Daskyleion’un Ticari İlişkileri. (Doktora Tezi). Ege Üniversitesi Sosyal Bilimler Enstitüsü, İzmir.

Koday, Z., Akbaş, F. ve Kaya, G. (2017). Akhisar Büyükşehir İlçesinin İdari Coğrafya Analizi. Atatürk Üniversitesi Sosyal Bilimler Enstitüsü Dergisi, 21(2), 443-455.

Konakçı, E. (2014). Laodikeia Asopos Tepesi Orta Tunç Çağı Seramiği. Arkeometri Sonuçları Toplantısı, 29 içinde (s. 63-76). Muğla: Muğla Sıtkı Koçman Üniversitesi Basımevi.

Korkut, T. (2007). Die spätantike und frühbyzantinische Keramik aus Patara. B. Böhlendörf ve ark. (Eds.), Byzas 7, Çanak. Late Antique and Medieval Pottery and Tiles in Mediterranean Archaeological Contexts/ Akdeniz Çevresindeki Arkeolojik Kazılarda Ele Geçen Geç Antik ve Ortaçă̆ Seramiği ve Mimari Seramiği içinde (s. 147-168). İstanbul: Ege Yayınları. 
Ladstätter. S. (2005). Keramik. H. Thür (Ed.), Hanghaus, 2 in Ephesos Die Wohneinheit 4 Baubefund, Ausstattung, Funde içinde, Forschungen in Ephesos, VIII/6. Wien.

Lichter, C. (2005). Western Anatolia in the Late Neolithic and Early Chalcolithic: the actual state of research. C. Lichter (Ed.), Byzas 2, How did Farming Reach Europe. Anatolian-European relations from the second half of the 7th through the first half of the 6th millenium cal BC içinde (s. 59-74). İstanbul: Ege Yayınlar1.

Lloyd, S.,\& Mellaart, J. (1962). Beycesultan I, The Chalcolithic and Early Bronze Age Levels. London: British Institute of Archaeology at Ankara.

Lloyd, S.,\& Mellaart, J. (1965). Beycesultan Vol II, Middle Bronze Age Architecture and Pottery. London: British Institute of Archaeology at Ankara.

Mellaart, J.,\& Murray, A. (1995). Beycesultan Vol III, Part II. Late Bronze Age and Phrgian Pottery and Middle and Late Bronze Age Small Objects. London: British Institute of Archaeology at Ankara.

Mellink, M. J. (1967). Excavations at Karataş-Semayük in Lycia, 1966. American Journal of Archaeology, $71(3), 251-267$.

Mierse, W. E. (1986). Lydian Pottery at Aphrodosias. Prehistoric Aphrodisias, An Account of the Excavations and Artifact Studies Vol. I. (pp. 413-424). Louvain: Brown University Press.

Mitsopoulos Leon, V. (1991). Die Basilika am Staatsmarkt in Ephesos Kleifunde. 1. Teil: Keramik hellenistischer und römischer Zeit. Forschungen in Ephesos IX 2/2, Wien.

Roosevelt, C. H. (2010). Lidyalılardan Önce Lydia/Lydia Before the Lydians. N. D. Cahill (Ed.), Lidyalılar ve Dünyalarl/The Lydians and Their World içinde (s. 37-73). İstanbul: Yapı Kredi Yayınları.

Roosevelt, C. H. (2017). Gyges 'ten Büyük İskender'e Lydia Arkeolojisi. İstanbul: Koç Üniversitesi Yayınları.

Schaus, G. P. (1992). Imported West Anatolian Pottery at Gordion. Anatolian Studies, 42, 151-177.

Takaoğlu, T. (2000). A Chalcolithic Marble Workshop at Kulaksızlar in Western Anatolia. An Analysis of Production and Craft Specialization. (Doktora Tezi). Boston University College of Arts and Sciences Archaeology, Boston.

Takaoğlu, T. (2001). 1999 Yılı Kulaksızlar Mermer Atölyesi Araştırması. Araştırma Sonuçları Toplantısı, 18(2) içinde (s. 157-168). Ankara: Kültür Bakanlığg1 Milli Kütüphane Basımevi.

Takaoğlu, T. (2002). Chalcolithic Marble Working at Kulaksızlar in Western Anatolia. TÜBA-AR, 5, 71-93.

Takaoğlu, T. (2004). Moralı: A Neolithic Mound in Central Western Anatolia. T. Korkut, H. İşkan, G. Işın (Ed.), Anadolu'da Doğdu-60. Yaşında Fahri Işık'a Armă̆an içinde (s. 743-751). İstanbul: Ege Yayınları.

Takaoğlu, T. (2005). A Chalcolithic Marble Workshop at Kulaksızlar in Western Anatolia. British Archaeological Reports (British Series), Oxford: Bar Publishing.

Takaoğlu, T. (2011). Stone Artefacts and Idols in Western Anatolia. V Şahoğlu \& P. Sotirakopoulou (Eds.), Across. The Cyclades and Western Anatolia during the 3rd Millenium BC içinde (s. 158-163). İstanbul: Sakıp Sabancı Müzesi.

Takaoğlu, T. (2017). Middle Chalcolithic finds from Dağdere in the Akhisar-Manisa Region. Anadolu/ Anatolia, 43, 1-13.

Wintermeyer, U. (2004). Die hellenistische und frühkaiserzeitliche Gebrauchskeramik: auf Grundlage der stratifizierten Fundkeramik aus dem Bereich der Heiligen Strasse. Mainz am Rhein: Philipp von Zabern. 


\section{RESIMMLER}

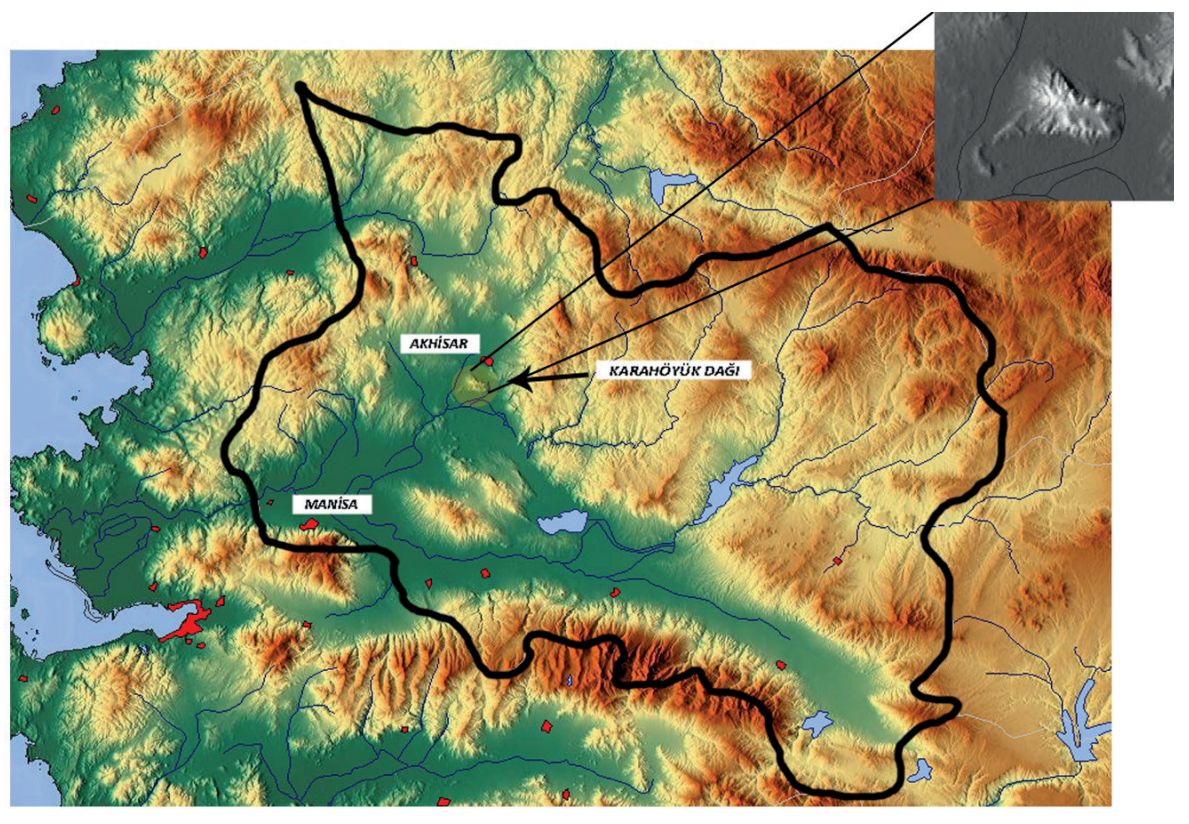

Resim 1. Karahöyük Dağı'nın yerini gösteren harita.

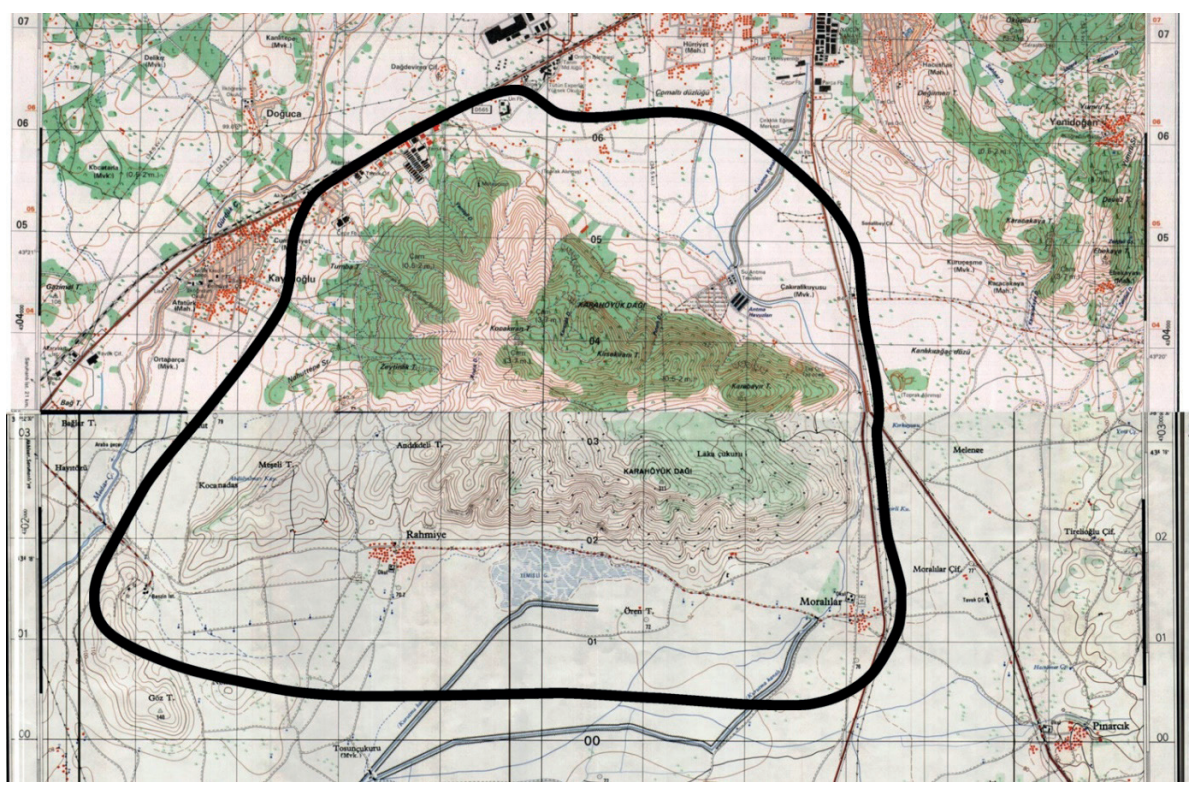

Resim 2. Araştırma sahasının haritası. 


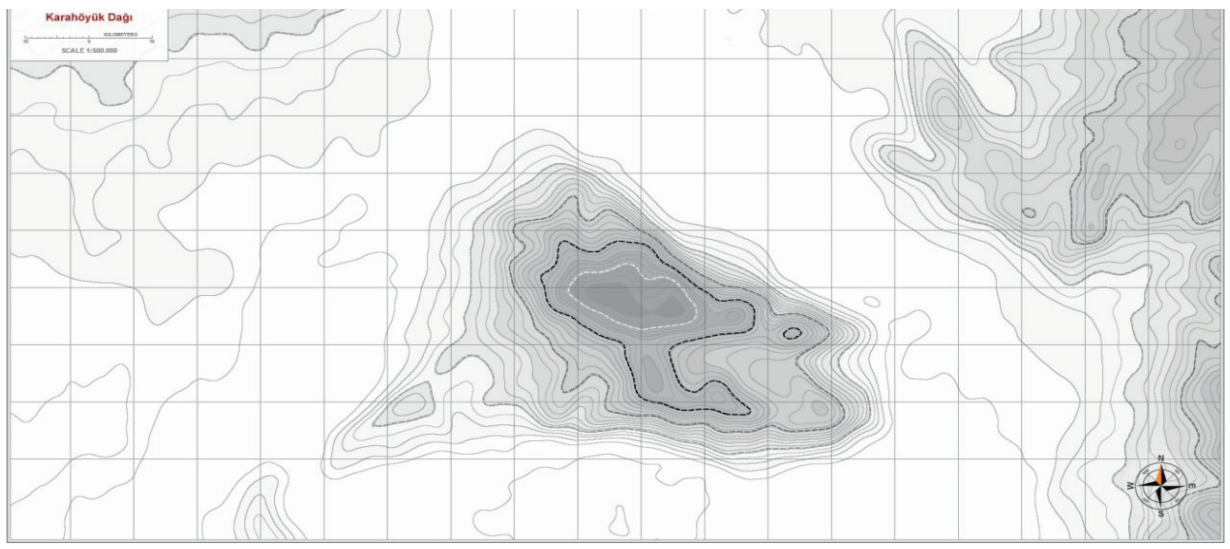

Resim 3. Karahöyük Dağı haritası. 

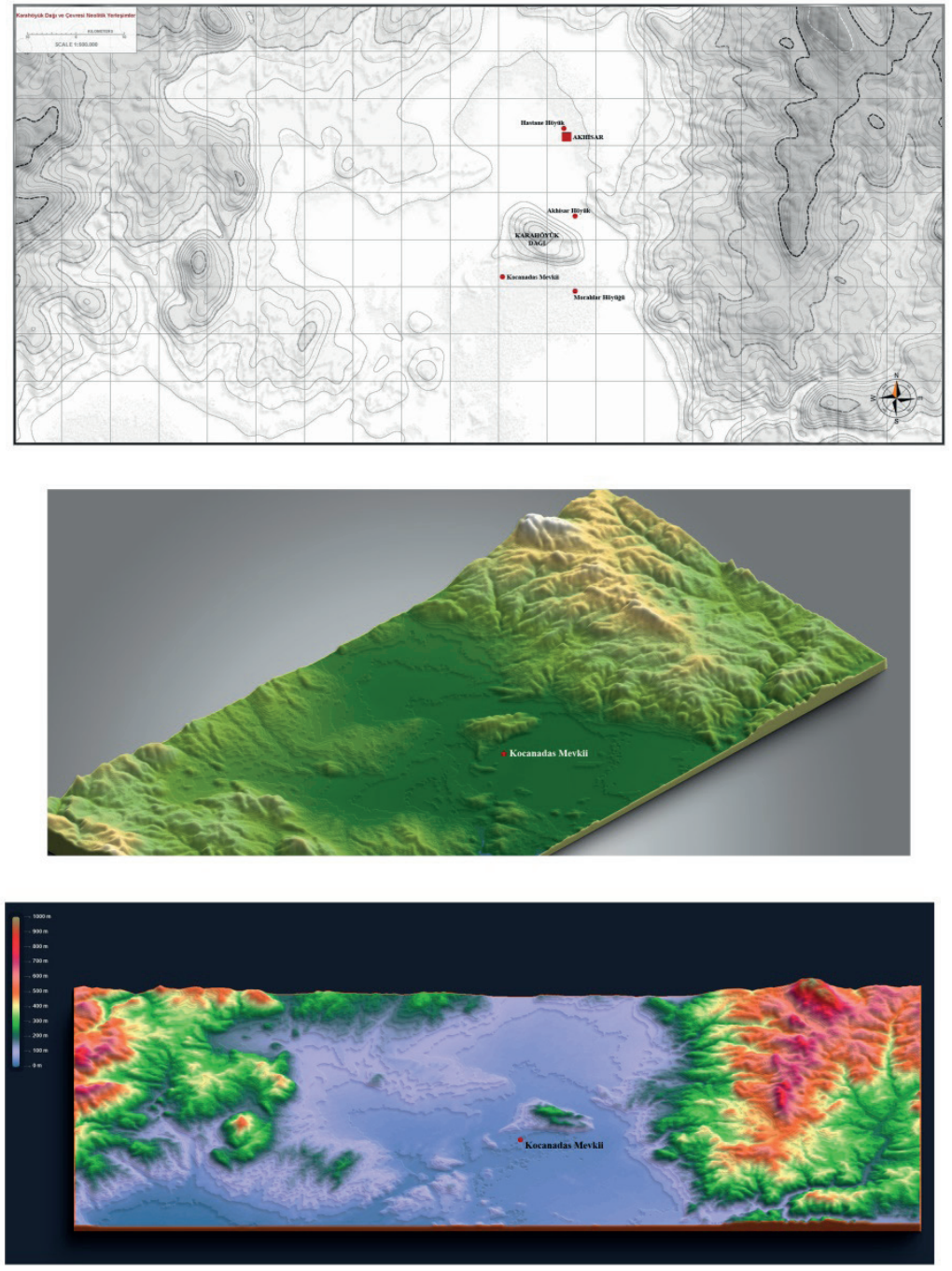

Resim 4. Karahöyük Dağı çevresinde yer alan geç neolitik çă̆ yerleşimlerinin yerini gösteren haritalar. 


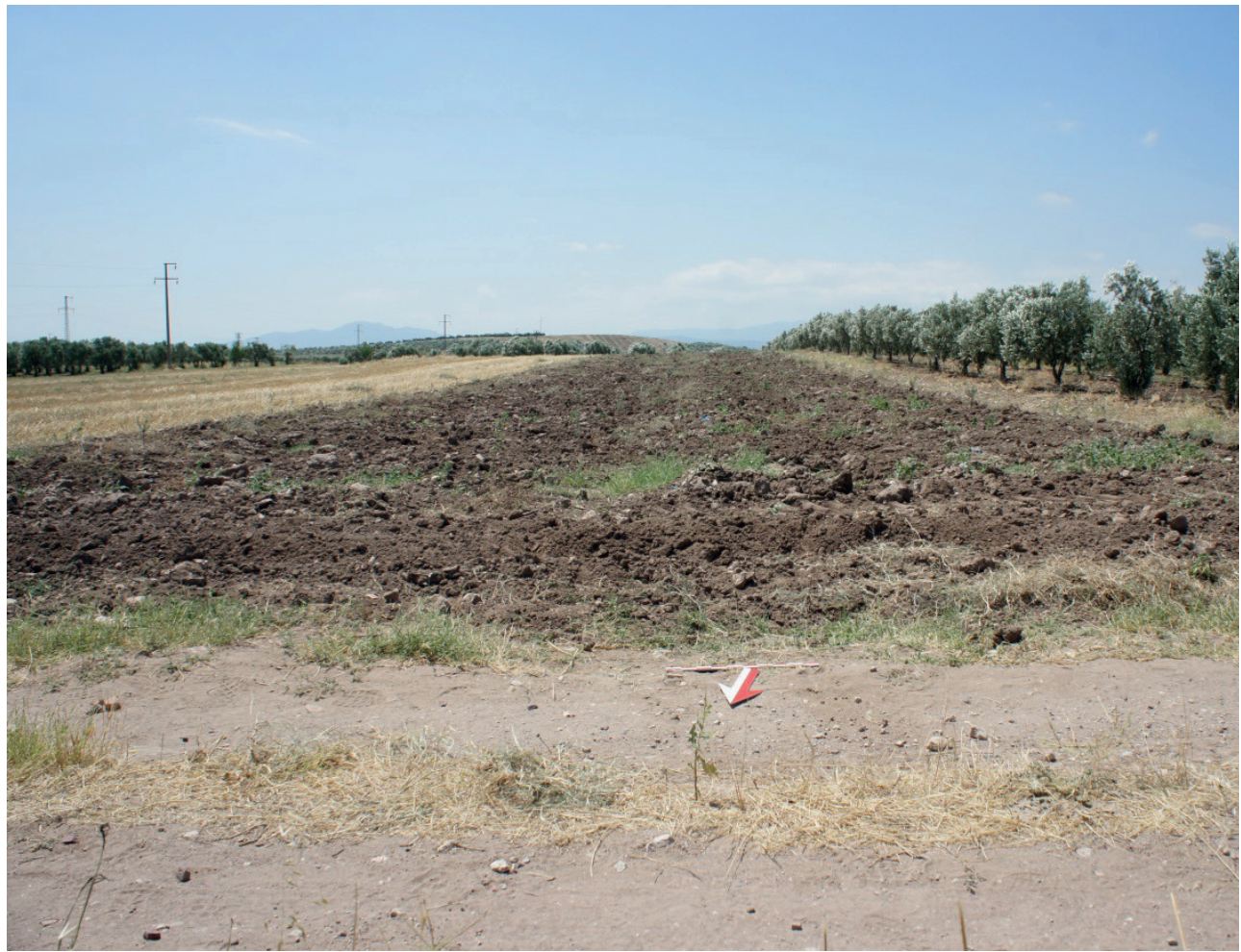

Resim 5. Kocanadas Höyüğü’nün kuzeyden görünüşü. 


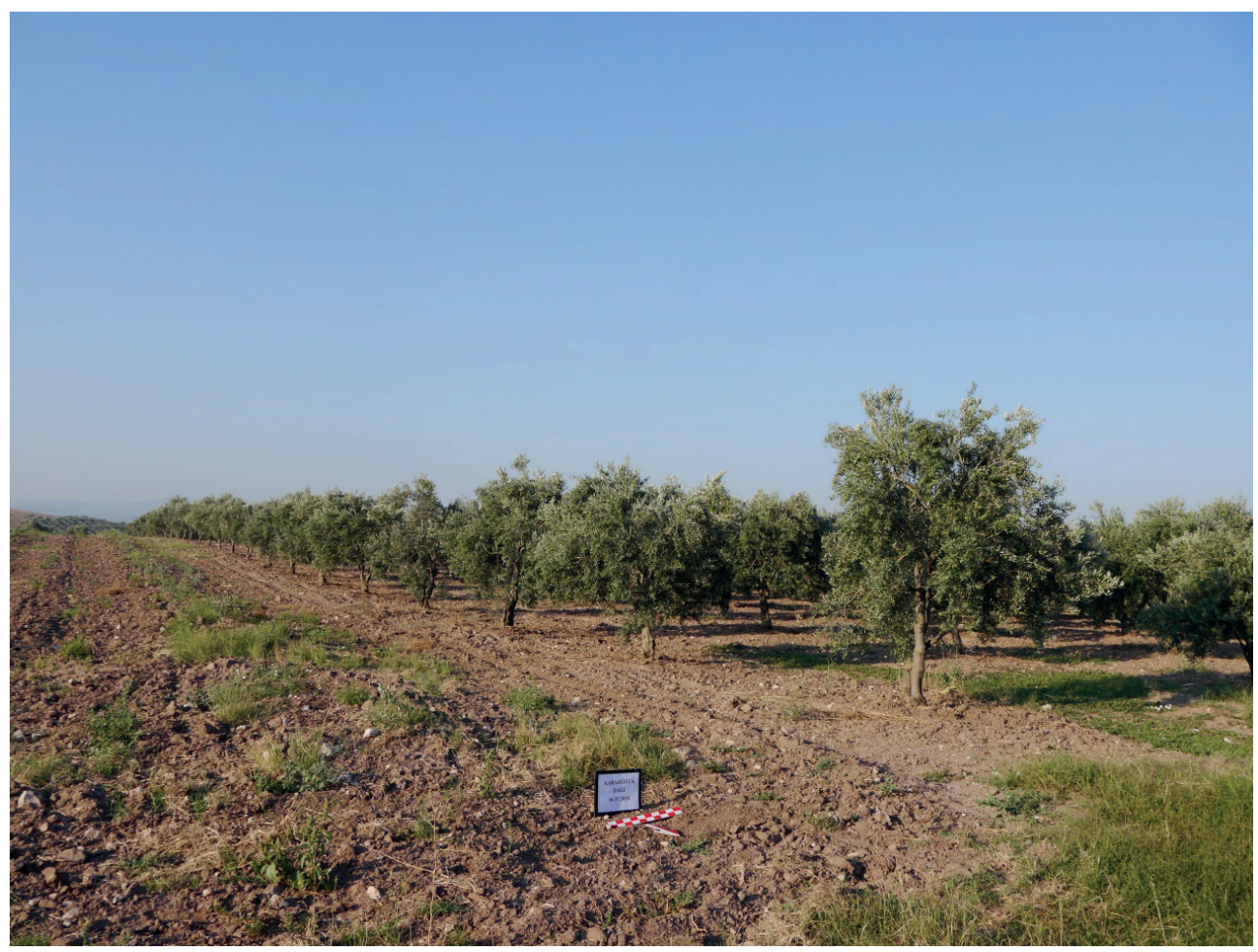

Resim 6. Kocanadas Höyüğü’nün kuzeyden görünüşü.

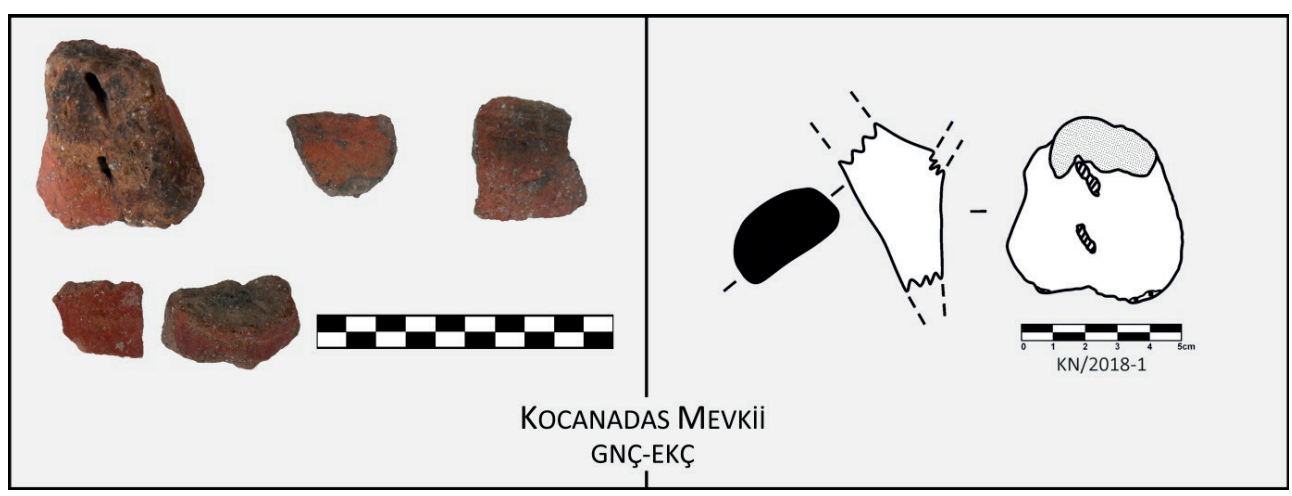

Resim 7. Geç Neolitik-erken Kalkolitik çağ seramikleri. 


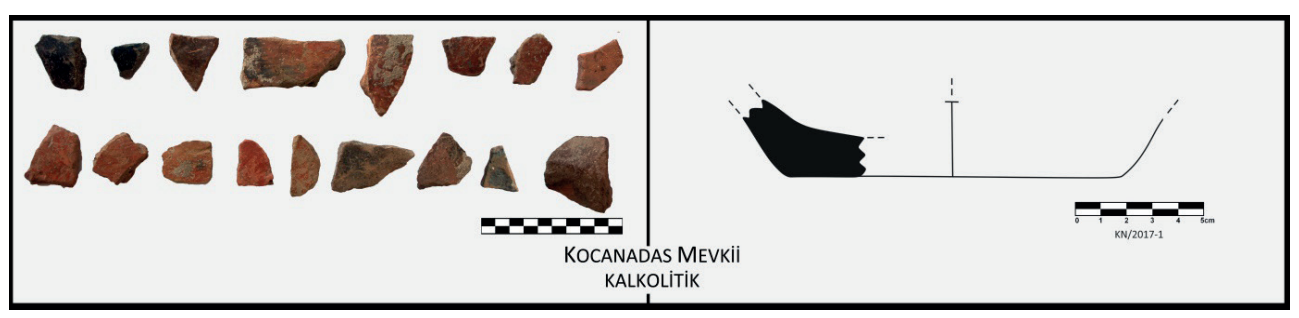

Resim 8. Son Kalkolitik çağ seramikleri.

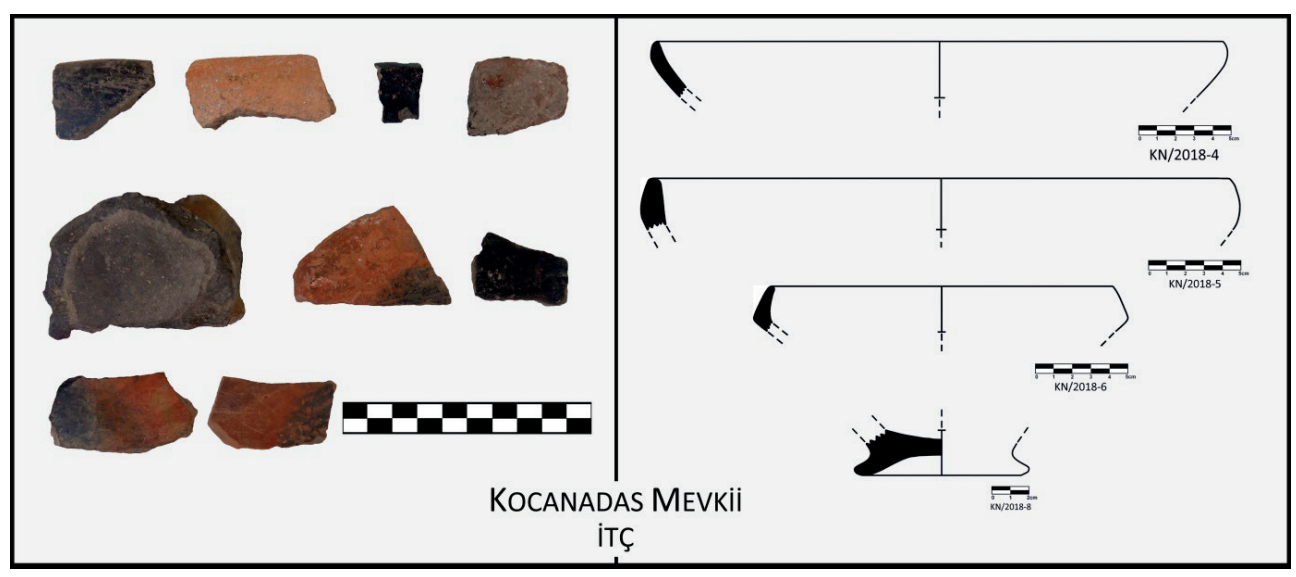

Resim 9. İlk Tunç çağı seramikleri.

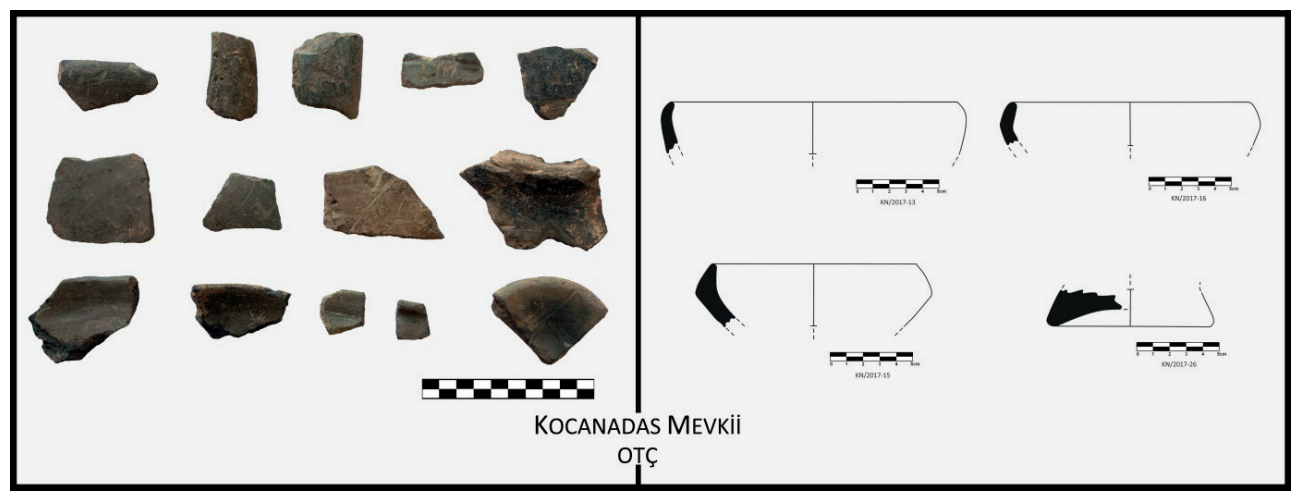

Resim 10. Orta Tunç çağı seramikleri. 


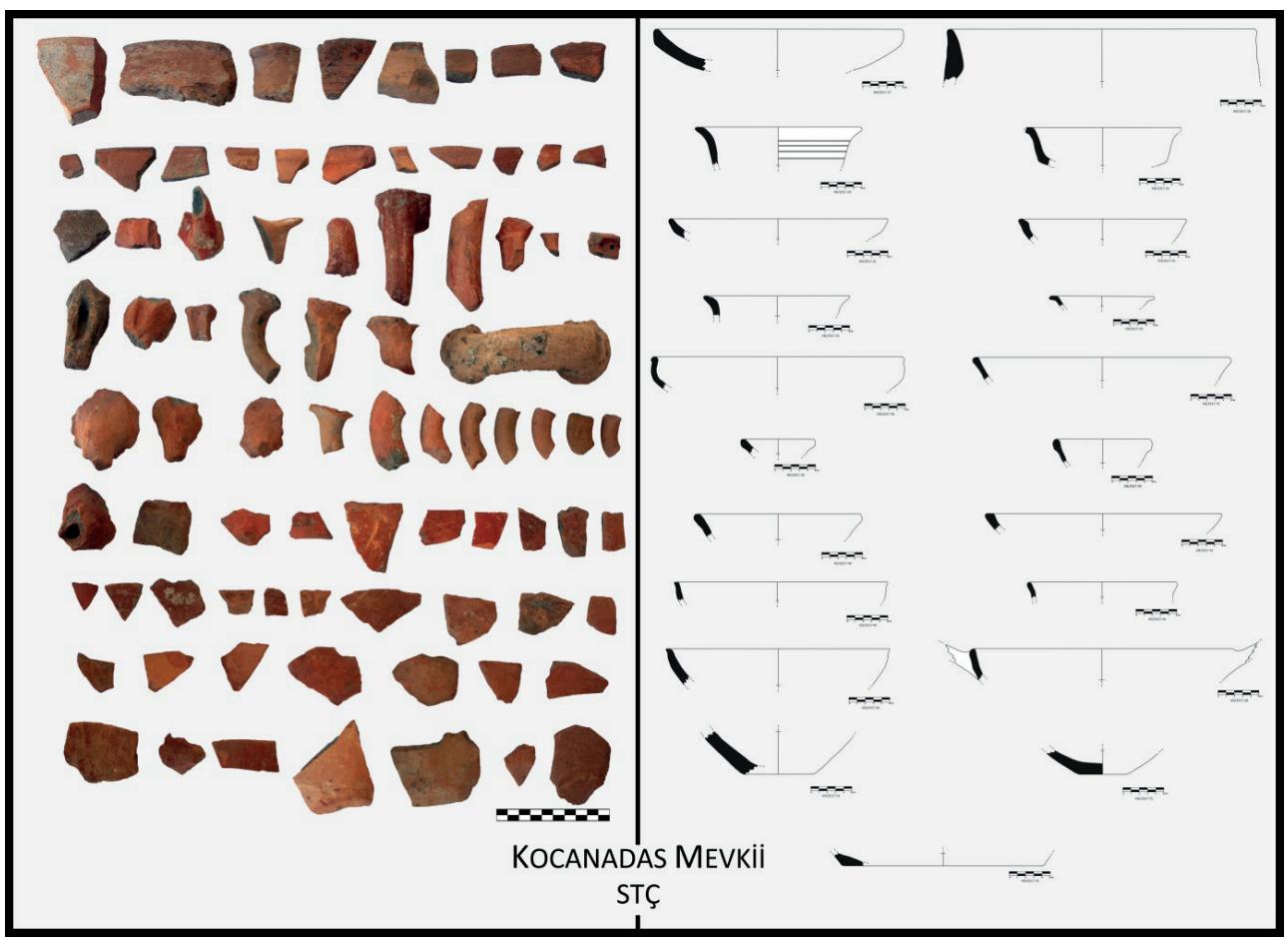

Resim 11. Son Tunç çağı seramikleri.

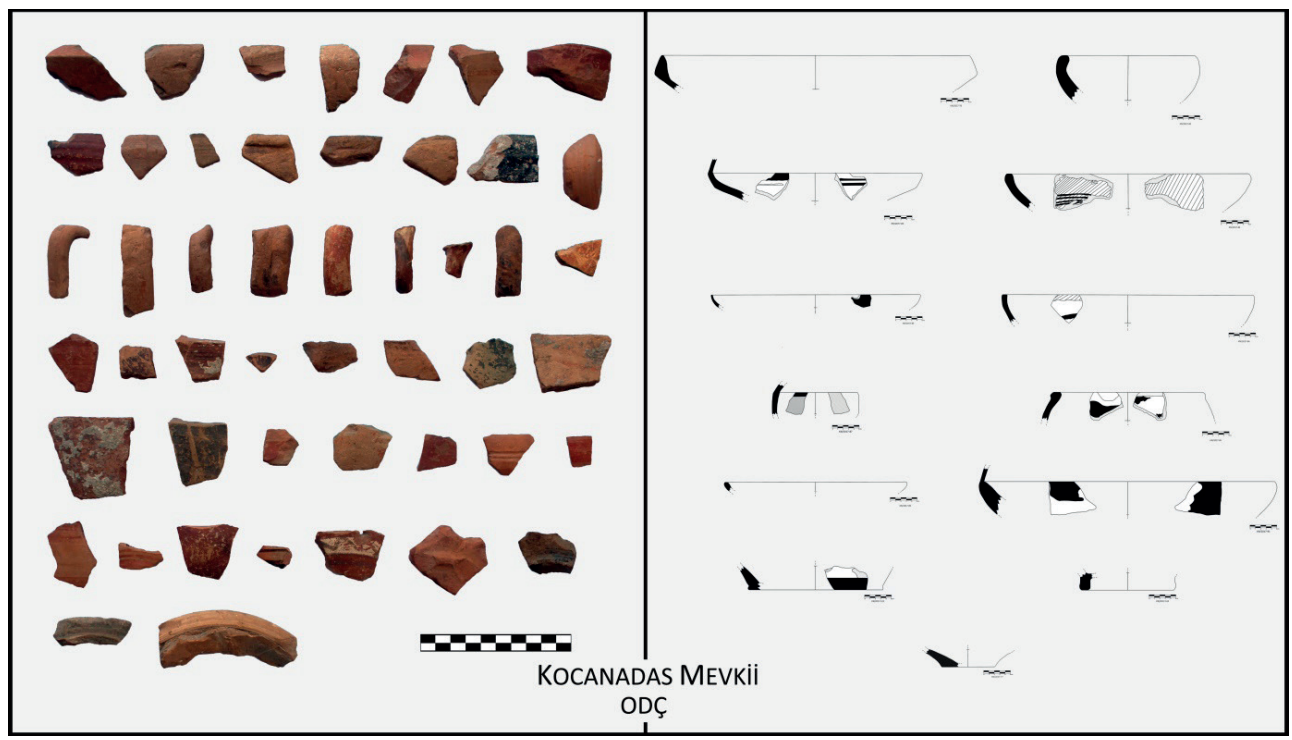

Resim 12. Demir çağı ve Lydia seramikleri. 


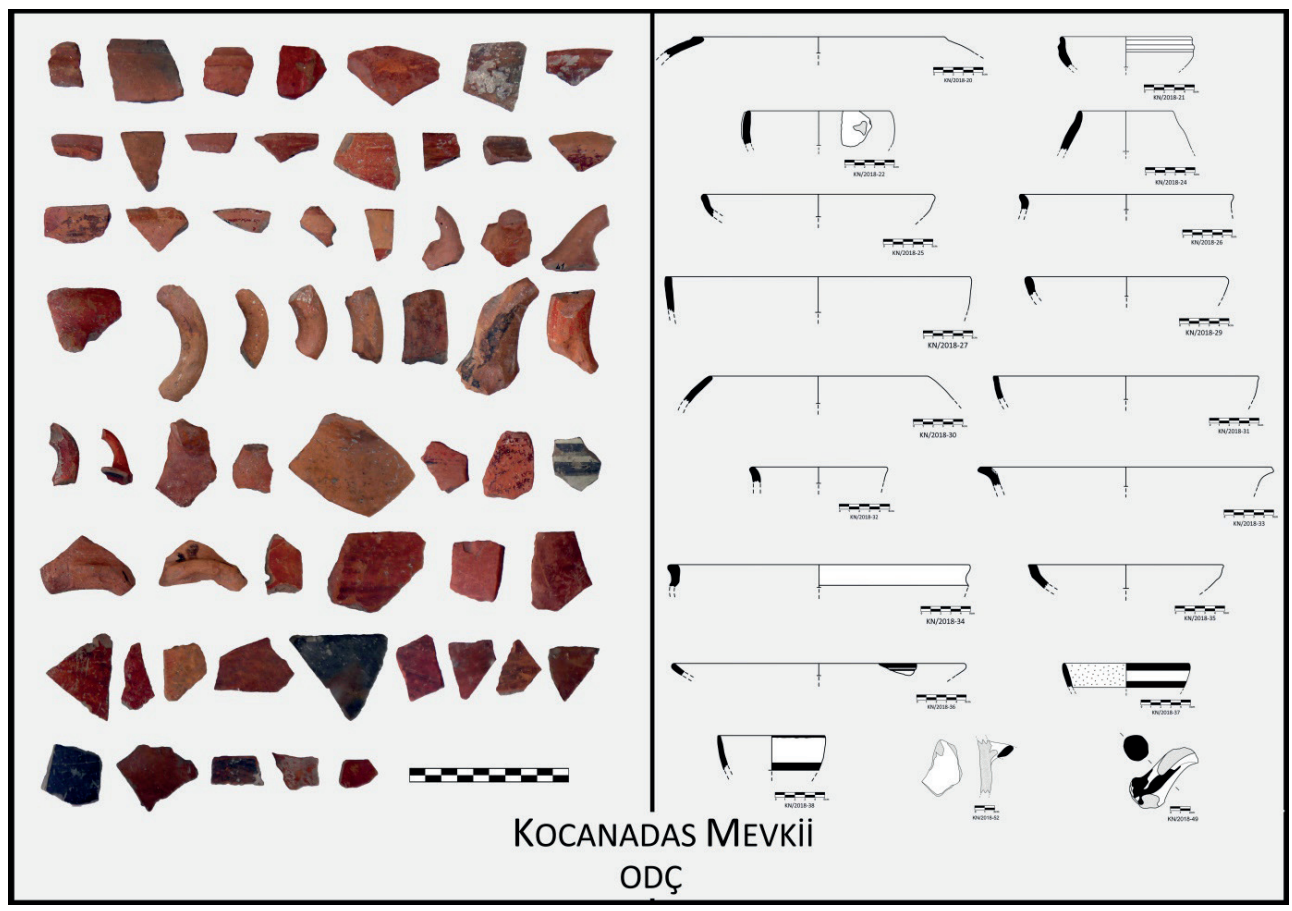

Resim 13. Demir çağı ve Lydia seramikleri.

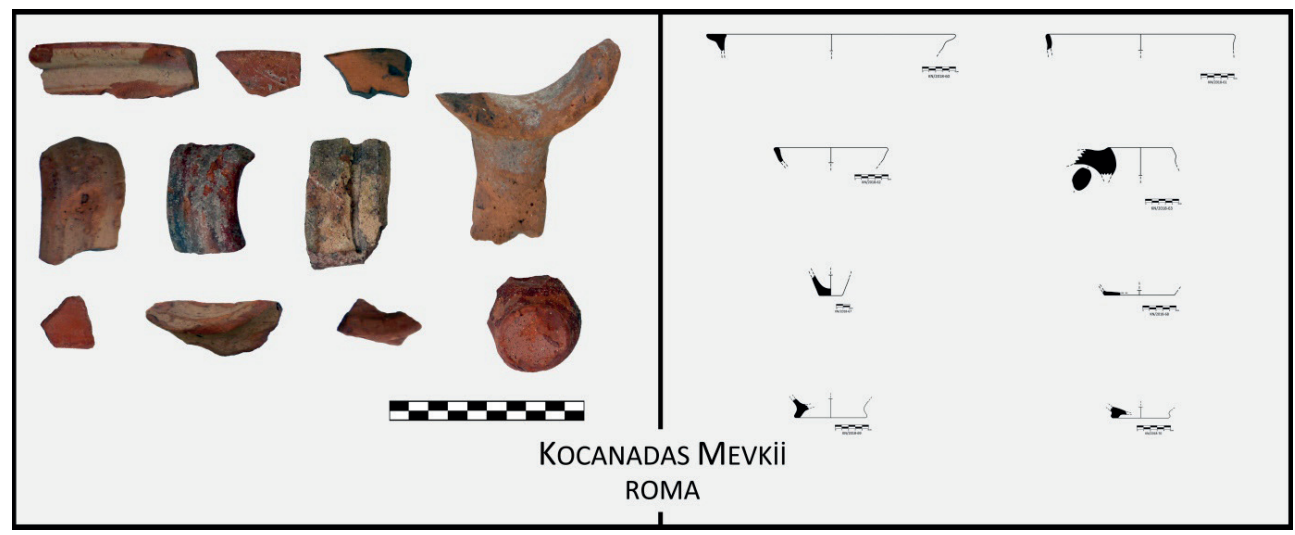

Resim 14. Roma çağı seramikleri. 


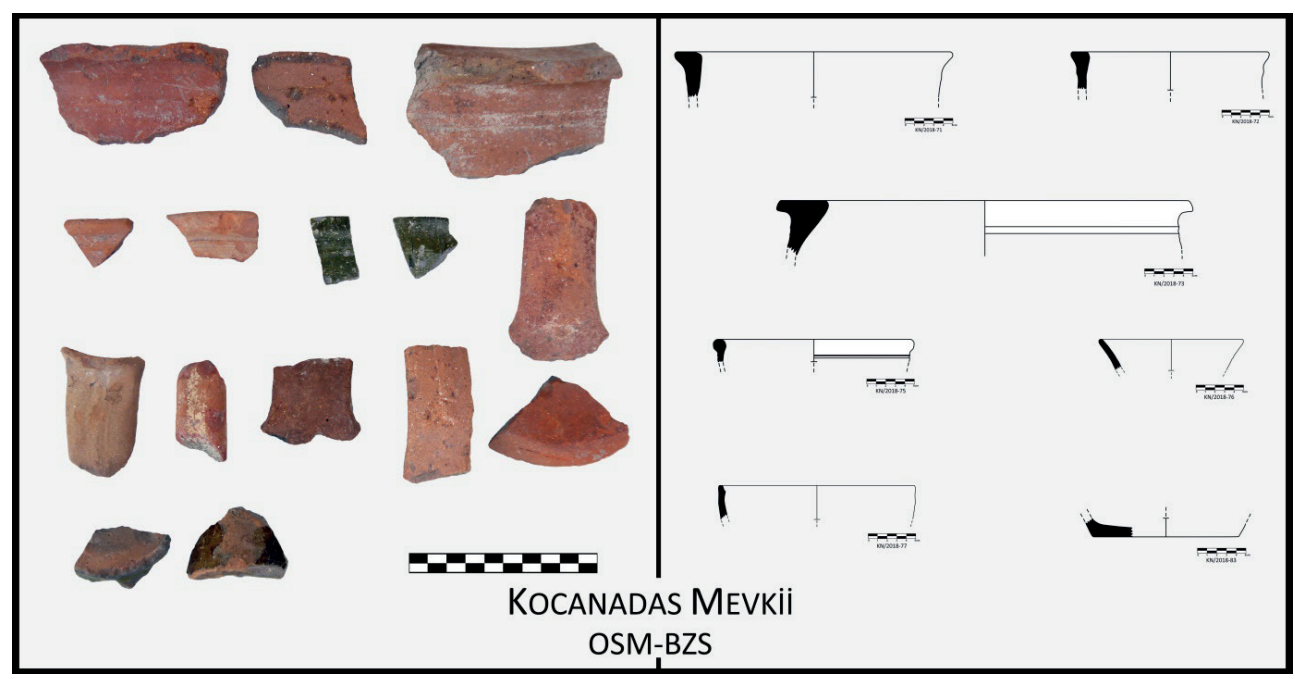

Resim 15. Bizans ve Osmanlı seramikleri.

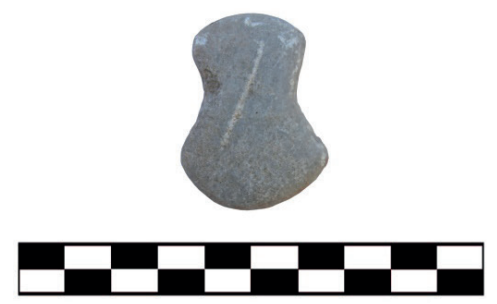

KD2017-ENV01

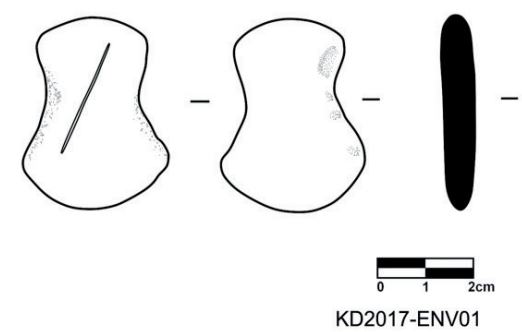

Resim 16. Taş idol. 

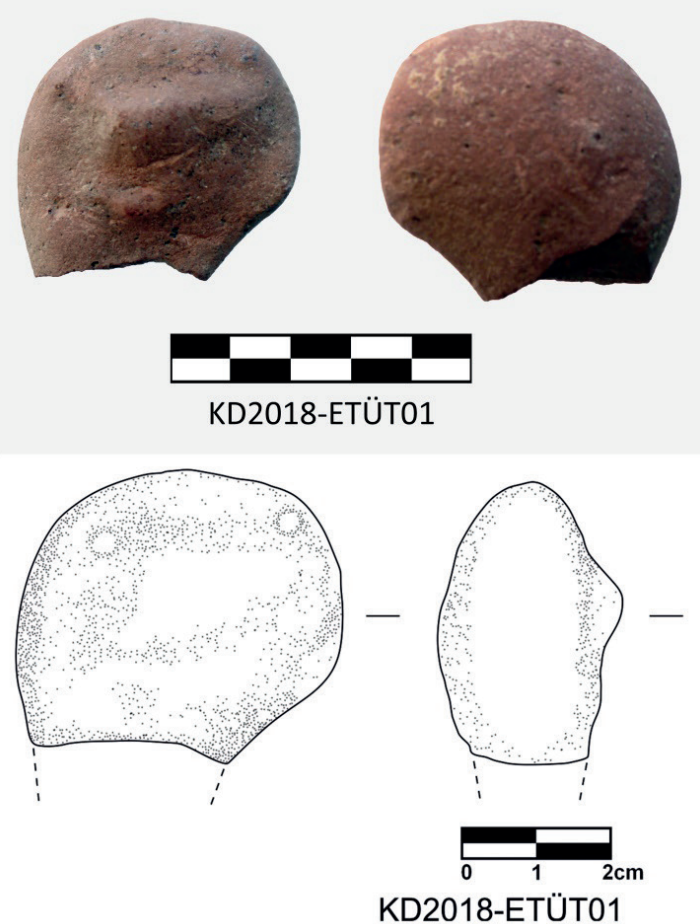

Resim 17. Pişmiş toprak idol.
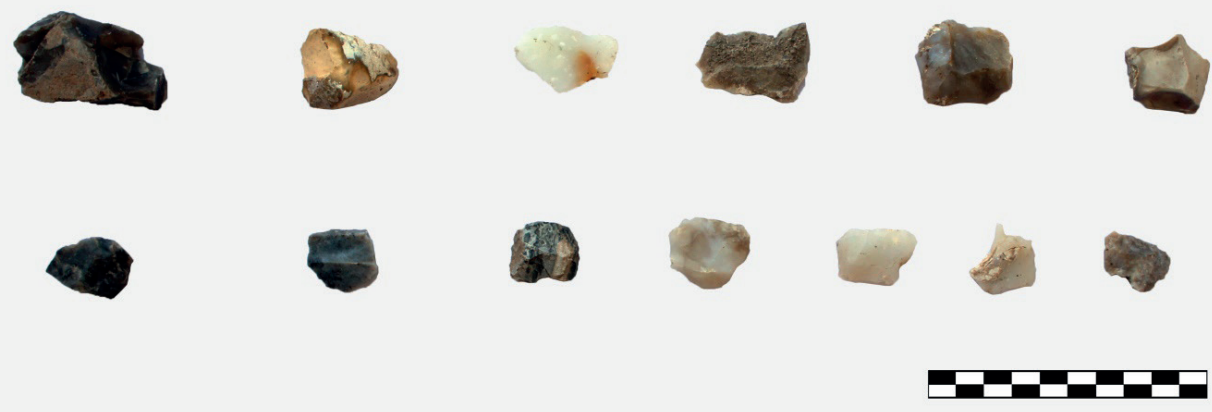

Resim 18. Çakmaktaşı buluntular. 

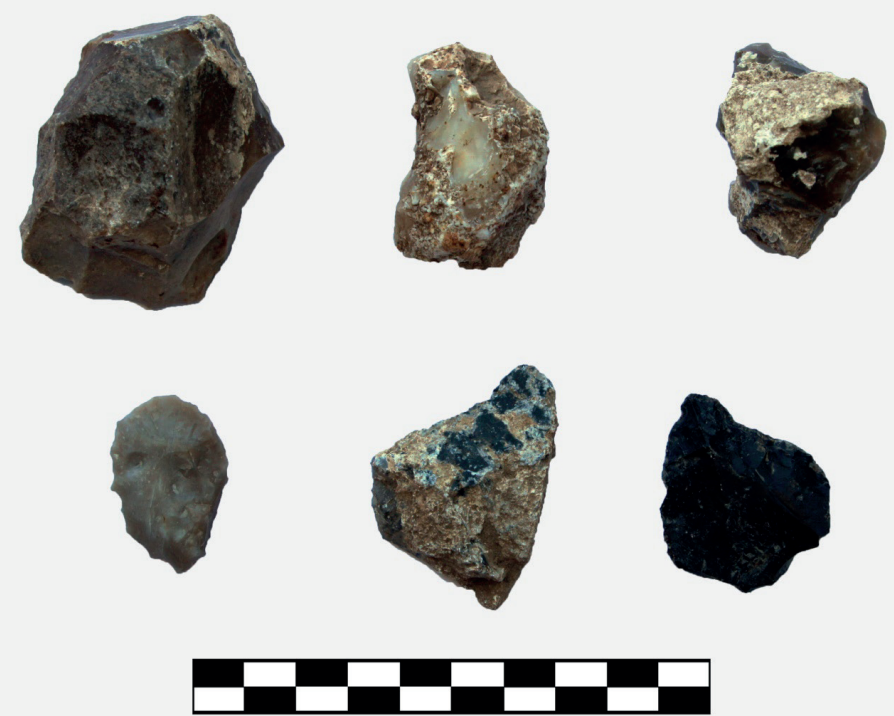

KOCANADAS MEVKIi

Resim 19. Çakmaktaşı alet buluntuları.
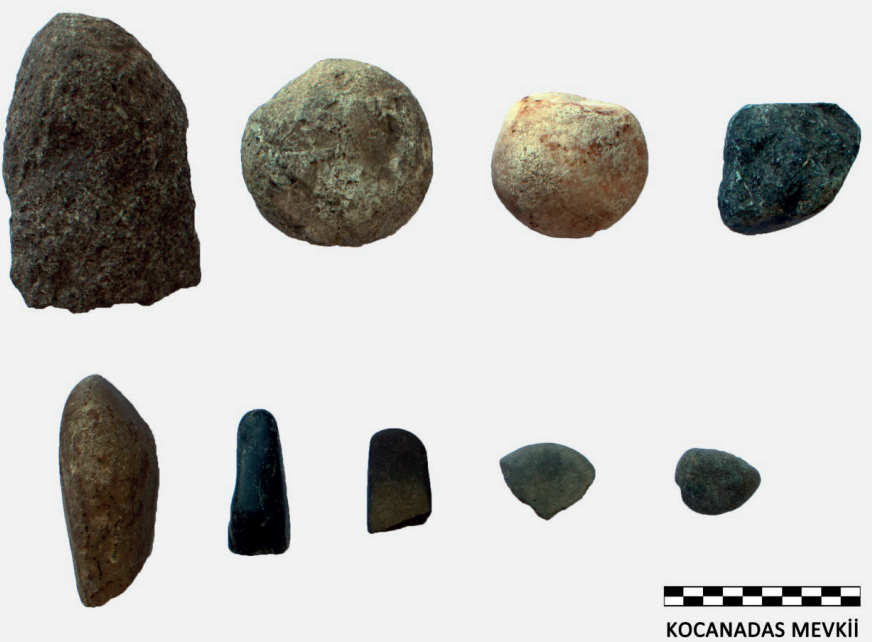

Resim 20. Taş alet buluntuları. 